\title{
Türkiye ve ABD’de Eğitim Yönetimi Alanında Hazırlanan Doktora Tezlerinin İncelenmesi ${ }^{1}$
}

\author{
Mustafa ÇELİK² ve Cemil YÜCEL ${ }^{3}$
}

$\ddot{O}_{z}$

Bu araştırmanın amacı Türkiye ve Amerika Birleşik Devletleri'nde (ABD) 2014-2018 yılları arasında eğitim yönetimi alanında hazırlanan doktora tezlerini demografik özellikler, konu, yöntem ve öneriler açısından değerlendirmektir. Araştırma sistematik derleme çalışması olarak desenlenmiştir. Araştırmanın evreni Türkiye ve ABD'de eğitim yönetimi alanında 2014-2018 yılları arasında hazırlanan doktora tezlerinden oluşmaktadır. Türkiye'deki doktora tezleri için örneklem seçimi yapılmamış olup evrenin tamamına ulaşılmaya çalışılmıştır. Araştırmaya, Türkiye'de eğitim yönetimi alanında hazırlanan 175 doktora tezi dâhil edilmiştir. ABD'deki doktora tezlerinin belirlenmesinde tabakalı örnekleme ile basit tesadüfi örnekleme yöntemleri kullanılmıştır. ABD'de eğitim yönetimi alanında 1476 doktora tezinin hazırlandığ1 tespit edilmiştir. \%95 güven düzeyi için örneklem 306 olarak belirlenmiştir. Ancak, çalışmanın geçerlik ve güvenirliğini arttırabilmek adına örnekleme 339 doktora tezi dâhil edilmiştir. Elde edilen bulgulara göre eğitim yönetimi alanında en fazla doktora tezi Türkiye'de 2017, ABD'de ise 2014 yllında hazırlanmıștır. Türkiye'de ve ABD'de hazırlanan doktora tezlerinde en çok örgüt ve örgütsel davranış ile yönetim konuları çalışılmıştır. Tezlerde, Türkiye'de en çok nicel araştırma yöntemi ve örneklem grubu olarak öğretmenler, ABD'de ise nitel araştırma yöntemi ve örneklem grubu olarak yöneticiler tercih edilmiştir. Tezlerde, her iki ülkede de örgüt, örgütsel davranış ve yönetim gibi konular sıklıkla işlenirken eğitim yönetiminde yeni yaklaşımlar gibi konulara çok az önem verilmiştir. Türkiye'de hazırlanan tezlerde pozitivist paradigmanın etkisi açıkça görülmektedir. Her iki ülkedeki tezlerde araştırmacılara yönelik benzer öneriler yapılmıştır.

Anabtar Kelimeler: Türkiye, ABD, Eğitim yönetimi, Doktora tezleri

\section{Examination of the PhD Thesis Prepared in the Field of Educational Administration in Turkey and in USA}

\section{Abstract}

The purpose of this research is to evaluate the PhD thesis prepared in the field of educational administration in Turkey and in USA between the years of 2014-2018 in terms of demographic characteristics, issues, methods and suggestions. The research was designed as a systematic review study. The universe of the study consists of PhD thesis that prepared in the field of educational administration in Turkey and in USA between 2014-2018 years. For the PhD thesis in Turkey, there was not made sample selection but was tried to reach the entire universe. $175 \mathrm{PhD}$ thesis prepared in the field of educational administration in Turkey are included into the study. The stratified sampling and the simple random sampling methods were used to determine the $\mathrm{PhD}$ thesis in USA. It was determined that $1476 \mathrm{PhD}$ thesis prepared in the field of educational administration in USA. The sample was determined as 306 for $95 \%$ confidence level. However, in order to increase the validity and reliability of the study, $339 \mathrm{PhD}$ thesis were included into the sample. According to the findings most of the PhD thesis in the field of educational administration in Turkey was prepared in 2017, while in USA was prepared in 2014. The issues most studied in the PhD thesis prepared in Turkey and in USA are the organization and organizational behavior and administration. In the $\mathrm{PhD}$ thesis, quantitative research method and teachers as sample group was most preferred in Turkey, while qualitative research method and administrators as sample group was most preferred in USA. In thesis, while certain issues such as organization, organizational behavior and administration are frequently studied in both countries, it was given little attention to some issues such as new approaches in educational administration. It can be seen the effect of positivist paradigm in the thesis prepared in Turkey. Similar suggestions have been made for the researchers in the $\mathrm{PhD}$ thesis in both countries.

Key Words: Turkey, USA, Educational administration, $\mathrm{PhD}$ thesis

\section{Atıf İçin / Please Cite As:}

Çelik, M., Yücel, C. (2021). Türkiye ve ABD’de Eğitim Yönetimi Alanında Hazırlanan Doktora Tezlerinin İncelenmesi. Manas Sosyal Arastirmalar Dergisi, 10(3), 1632-1651.

Geliş Tarihi / Received Date: 03.05.2021

Kabul Tarihi / Accepted Date: 19.05.2021

\footnotetext{
${ }^{1}$ Bu makale ikinci yazarın danışmanlı̆̆ında hazırlanan doktora tez çalışmasından üretilmiştir.

2 Arş. Gör. Dr. - Kütahya Dumlupınar Üniversitesi Eğitim Fakültesi, mustafa.celik@dpu.edu.tr

(D) ORCID: 0000-0001-6825-315X

3 Prof. Dr. - Eskişehir Osmangazi Üniversitesi Eğitim Fakültesi, cemilyucel@gmail.com ID ORCID: 0000-0003-4183-8136
} 


\section{Giriş}

İnsan doğumundan ölümüne kadar sosyal bir öğrenme faaliyeti içerisinde olduğundan eğitim, insanın doğumundan ölümüne kadar yaşadığı hayatı her yönüyle etkileyen bir süreçtir. Bu bağlamda eğitim toplumların geleceklerinin belirlenmesinde önemli bir yer almaktadır (Yllmaz, 2015, s. 1-2). Eğitim, formal ve informal eğitim olmak üzere temelde ikiye ayrılmaktadır. Formal eğitim de, örgün ve yaygin eğitim olmak üzere ikiye ayrrlmaktadır. Örgün eğitim ise, okulöncesi eğitim, ilköğretim, ortaöğretim ve yükseköğretim kurumlarında gerçekleştirilen eğitim faaliyetlerini kapsamaktadır. Örgün eğitimin bir aşaması olan yükseköğretim de ön lisans, lisans ve lisansüstü eğitim aşamalarından oluşmaktadır (Yılmaz, 2015, s. 3-5).

Lisansüstü eğitim, lisans eğitimi tamamlandıktan sonra, araştırma yaparak bilim ve teknoloji üretmeyi amaç edinen, ülkenin gelişmesinde ve kalkınmasında önemli rol oynayacak bilim insanı yetiştirme misyonunu üstlenmiş, planlı ve programlı bir eğitim sürecidir (Varış, 1972, s. 52). Lisansüstü eğitimin amaçları arasında yükseköğretime, kamu ve sanayi sektörünün çeşitli hizmet alanlarına nitelikli insan gücü yetiştirmek bunun yanı sıra ülke sorunlarını çözmeye, kalkınma için gerekli bilim ve teknolojiyi üretmeye yönelik araştırmalar yapmak yer almaktadır (Karakütük, 1989, s. 506). Yapılan lisansüstü eğitimleri süresince öğretim üyesi, öğrenci, eğitim programları, çalışma birimleri ve şartlarılyla ilgili birçok sorun yaşanmaktadır (Karaman ve Bakırcı, 2010, s. 94). Yaşanan bu sorunlardan bir tanesi de hazırlanan lisansüstü tezlerindeki nitelik sorunlarıdır. Bu bağlamda belli bir alanda hazırlanan lisansüstü tezlerinin incelenmesi ve alanla ilgili genel bir resmin ortaya konulması gerekli görülmektedir.

Belirli bir alan ile ilgili yapılmış bilimsel araştırmaların analiz edilip değerlendirilmesi hem o konunun derinliği ve yaygınlığı hakkında bilgi vermekte hem de ilgili alanın genel görünümünü ortaya sunmaktadır. Bununla birlikte, yapılan bu değerlendirmeler yalnızca ilgili konu alanının değil bilimin bir bütün olarak kendini sorgulayıp geliştirmesi açısından da oldukça önemlidir. Ayrıca, üretilen bilimsel bilgi ve üretim yöntemlerinin dünü ve bugünü arasında karşılaştırmalar yapmak, geleceğe ilişkin analitik ve gerçekçi yaklaşımlar oluşturmayı da kolaylaştırmaktadır (Turan, Karadağ, Bektaş ve Yalçın, 2014, s. 94).

Oplatka’ya (2016) göre eğitim yönetimi alanı, bir çalışma alanı olarak yaklaşık yüz yılı geride bırakmış durumdadır. Eğitim yönetimi alanı kendine özgü teori ve kavramlara sahip olmayıp, sosyal bilimlerden alınan teori ve kavramlar üzerine inşa edilmeye çalışılmış bir alandır. Alanın temelleri ABD'de ve İngiltere'de atılmıştır. Bu bağlamda da eğitim yönetimi alanının bugünkü var olan mirası bu iki ülkede üretilen bilimsel çalışmaların neticesinde şekillenmiştir. Eğitim yönetimi alanının Türkiye'deki durumu değerlendirildiğinde ise, üretilen bilgi bakımından Batılı ülkelerden geri olmadığı söylenebilir. Başka bir ifadeyle, Türkiye'de eğitim yönetimi alanında yapılan çalışmaların büyük çoğunlukla ABD ve İngiltere'den ithal edilmiş durumdadır. Ancak, kendi tarihi birikim ve bağlamına uygun araştırma yapmayan toplumlar da taklitte boğulma ve ithal bilgi distribütörlügünün ötesine geçemeyeceklerdir (Oplatka, 2016, s. v-vi). Bununla birlikte, Türkiye, eğitim yönetimi alanında üretilen bilimsel bilginin yoğun bir şekilde aktarıldığı ülkeler arasında ilk sıralarda yer almaktadır. Bu durumu görebilmek için ilgili alanyazındaki terminolojiye göz atmak yeterli olacaktır (Turan ve Şişman, 2013, s. 506). Bu bağlamda, Türkiye'de eğitim yönetimi alanında hazırlanan akademik çalışmaların incelenmesi mevcut durumun (güncel durumun) değerlendirmesini yapabilmek açısından önemli görülmektedir.

Eğitim bilimlerinin Türkiye'de üniversiter yapı içinde yer almasıyla önce eğitim sosyolojisi, eğitim tarihi, eğitim psikolojisi gibi disiplinler ortaya çıkmış, sonrasında ise bu disiplinler eğitim bilimleri adı altında anılmaya başlamıştır. 1981 yılında 2547 sayılı kanunla birlikte eğitim enstitüleri, eğitim fakültelerine dönüştürülmüştür. Bu dönüşüm sonrasında eğitim fakülteleri, Ankara Üniversitesi Eğitim Bilimleri Fakültesini model alarak eğitim bilimleri alanlarında lisansüstü programlar açmaya başlamışlardır. Ancak programlar açılırken gerekli ölçütlerin göz önünde bulundurulmaması eğitim bilimleri alanlarındaki lisansüstü programların kalitesini düşürmekle kalmayıp bu fakültelerin kuruluş misyonları olan öğretmen yetiştirmeyi ihmal etmelerine de neden olmuştur. Yaşanan bu gelişmeler sonrasinda Yükseköğretim Kurulu (YÖK), 1997 yllında eğitim fakültelerini yeniden yapılandırmış ve eğitim fakülteleri bünyesinde yer alan eğitim yönetimi bölümlerini kapatarak anabilim dalı düzeyine indirgemiştir (Balc1, 2008, s. 197).

Demirhan'a (2015) göre eğitim yönetimi alanı; kendi kuramsal temellerine sahip olmayan, bilimsel faaliyetlerini ithal ve belli bir tarihsel, siyasal, sosyal, kültürel bağlam içerisinde üretilmiş kuram ve yaklaşımlar üzerinden sürdüren bir alan olarak tanımlanmaktadır. Eğitim yönetimi alanı, 1950’li yıllarda ABD'de eğitim görerek alanın kurucuları olarak ülkemize dönen Prof. Dr. Ziya Bursalığlu gibi bilim 
insanlarının, transfer ettiği, o dönemde eğitim gördükleri ülkenin siyasi, iktisadi, toplumsal ve kültürel bağlamında, işletme, yönetim-organizasyon, psikoloji, sosyoloji gibi alanlardan transfer edilen konular üzerinde yoğunlaşmaktadır. Temel çalışma alanını oluşturan bu konular, 1950’li yıllarda bütün sosyal bilim alanlarında olduğu gibi, Eğitim yönetimi alanını da etkileyen modernist ve pozitivist yaklaşımlar tarafından üretilmiş ve üzerinde çalışılmış konulardır (Demirhan, 2015, s.125-129). 19. yüzyıldan itibaren bilimsel araştırmalara konu olan eğitim yönetimi, genel olarak geleneksel ve modern olarak nitelenen yönetim yaklaşımlarının etkilerine maruz kalmıştır. Endüstri devrimiyle birlikte geleneksel yönetim yaklaşımlarının etkinliğini kaybetmeye başladığı zamanlarda, aydınlanma düşüncesinin temel kavramları etrafında şekillenen ve modern olarak tanımlanan paradigmaların etkinliğini görmek mümkündür (Aslanargun, 2007, s. 196-197). Eğitim yönetimi alanı, 20. yüzyılın ikinci yarısında kendi kimliğini oluşturma sürecine giren ve ayrı bir çalışma alanı olarak değerlendirilmeye başlanan bir alandır. Eğitim yönetimi alanı bu dönem içerisinde çeşitli alanlarda gözlenen kuramsal gelişmelerden ve bu kuramların yönetim alanına yansımalarından kaçınılmaz bir şekilde etkilenmiştir (Beycioğlu ve Dönmez, 2006, s. 323-324).

Türkiye'deki eğitim yönetimi araştırmalarının mevcut durumunu daha iyi görebilmek adına dünyadaki eğitim yönetimi araştırmalarının durumunu yansıtmak da iyi bir yol olacaktır (Balc1, 2008, s. 199). İlgili alanyazın incelemesi sonucunda, eğitim yönetimi alanında hazırlanan doktora tezlerinin incelenmesiyle ilgili yapilan az sayıda (Aydın ve Uysal, 2011; Konan ve Kış, 2013) karşılaştırma çalışsmasına rastlanmıştır. Bu noktadan hareketle, yapilacak olan bu karşılaştırma çalışması ilgili alanyazındaki boşluğu doldurması ve ilgili alanın genel görünümünü ortaya çıkarması bakımından da önemli görülmektedir. Bu bağlamda, bu araştırmanın temel amacı Türkiye ve ABD'de eğitim yönetimi alanında hazırlanan doktora tezlerini demografik özellikler, konu, yöntem, öneriler ve kaynakça açısından değerlendirmek ve gelecekte bu konu ile ilgili yapılacak çalışmalara 1şık tutmaktır. Belirlenen bu genel amaç doğrultusunda aşağıdaki sorulara yanıt aranmiştır:

1. 2014-2018 yılları arasında Türkiye ve ABD'de eğitim yönetimi alanında hazırlanan doktora tezlerinin demografik özellikleri (yıl, üniversite, enstitü) nasıl bir dağılım göstermektedir?

2. 2014-2018 yılları arasında Türkiye ve ABD'de eğitim yönetimi alanında hazırlanan doktora tezleri konu bakımından nasıl bir dağılım göstermektedir?

3. 2014-2018 yılları arasında Türkiye ve ABD'de eğitim yönetimi alanında hazırlanan doktora tezleri kullanılan yöntemler (nicel, nitel, karma) bakımından nasıl bir dağılım göstermektedir?

a. 2014-2018 yılları arasında Türkiye ve ABD'de eğitim yönetimi alanında hazırlanan doktora tezleri araştırma modeli (tarama, nedensel, ilişkisel vb.) açısından nasıl bir dağllım göstermektedir?

b. 2014-2018 ylları arasında Türkiye ve ABD'de eğitim yönetimi alanında hazırlanan doktora tezleri evren, örneklem grupları açısından nasıl bir dağılım göstermektedir?

c. 2014-2018 yılları arasında Türkiye ve ABD'de eğitim yönetimi alanında hazırlanan doktora tezleri örnekleme yöntemleri açısından nasıl bir dağılım göstermektedir?

d. 2014-2018 yılları arasında Türkiye ve ABD'de eğitim yönetimi alanında hazırlanan doktora tezleri veri toplama araçları açısından nasıl bir dağılım göstermektedir?

e. 2014-2018 ylları arasında Türkiye ve ABD'de eğitim yönetimi alanında hazırlanan doktora tezleri geçerlik-güvenirlik çalışmaları açısından nasıl bir dağılım göstermektedir?

f. 2014-2018 ylları arasında Türkiye ve ABD'de eğitim yönetimi alanında hazırlanan doktora tezleri verilerin analizinde kullanılan istatistiksel teknikler açısından nasıl bir dağılım göstermektedir?

4. 2014-2018 yılları arasında Türkiye ve ABD'de eğitim yönetimi alanında hazırlanan doktora tezlerinde alan için katkı sağlayacağı düşünülen öneriler hangi başlıklar altında toplanmaktadır?

\section{Yöntem}

Çok sayıda araştırma sonuçlarının bir sentezinin, politika ve uygulama için genellikle tek bir araştırma sonuçlarından daha iyi bilgi sağladığı yaygın olarak kabul edilmektedir. Bu nedenle, sosyal araştırmaları gözden geçirmek ve bu bilgileri karar verme noktasında kullanmak için alanyazındaki araştırmacılar tarafindan bazı çalışmalar ortaya çıkmıştır (Littell, 2006, s. 535). Bu çalış̧ma türlerinden biri de sistematik derleme çalışmalarıdır. Sistematik derleme çalışmaları, alanında uzman kişiler tarafından benzer yöntemler ile yapılmış çok sayıdaki araştırmanın yapılandırılmış ve kapsamlı bir sentezidir (Karaçam, 2013, s. 26). Sistematik derleme çalışmaları belli bir konuda yapılmış araştırmaların detaylı ve geniş bir şekilde tarandıktan sonra belirli dışlanma ve dâhil edilme kriterleri kullanılarak, bulguların sentezlendiği bilimsel incelemelerdir (Aslan, 2018, s. 62). Bununla birlikte, sistematik derleme çalışmalarını, belli bir araştırma 
sorusuna yanıt aramak adına, araştırma sorusu ile ilgili yayınların önceden belirlenmiş kriterler doğrultusunda bir araya getirilerek sentezlenmesi şeklinde tanımlamak da mümkündür (Yılmaz, 2021, s. 1461).

Sistematik derleme çalışmaları bir bakıma büyük bilgi yığınlarını anlamlandırma yöntemidir. Özellikle belirli bir soruyu cevaplamak için ilgili tüm çalışmaları tanımlamaya, değerlendirmeye ve sentezlemeye çalışarak açıkça sistematik bir hatayı (önyarg1) sınırlamayı amaçlayan bir dizi bilimsel yönteme yakından bağlı alanyazın incelemeleridir. (Petticrew ve Roberts, 2006, s. 2-3). Sistematik derleme çalışmaları, incelenen bir soruya yanıt oluşturmak için, o alanda yapılmış olan çalışmaların kapsamlı bir biçimde taranması esasına dayanmaktadır (Yılmaz, 2018, s. 126; 2019, s. 85). Bu bağlamda, Türkiye ve ABD'de eğitim yönetimi alanında hazırlanmış doktora tezlerinin incelenmesi amacıyla yapılan bu çalışma sistematik derleme çalışması olarak desenlenmiştir.

\section{Evren - Örneklem}

Çalışmanın evreni Türkiye ve ABD’de eğitim yönetimi alanında 2014-2018 yılları arasında hazırlanan doktora tezlerinden oluşmaktadır. Türkiye'deki doktora tezlerine Ulusal Tez Merkezinden, ABD'deki doktora tezlerine ise ProQuest veri tabanından ulaşılmıştır. Çalışmada Türkiye'de eğitim yönetimi alanında hazırlanan doktora tezleri için örneklem seçimi yapılmamış olup evrenin tamamına ulaşılmaya çalışılmıştır. Ancak Ulusal Tez Merkezinde erişim izni verilmeyen doktora tezleri çalışma kapsamı dışında tutulmuştur. Yapılan taramalarda tam metin halinde erişilebilen doktora tezleri çalışma kapsamına dâhil edilmiştir. Yapılan taramalar sonucunda Türkiye'de eğitim yönetimi alanında 2014-2018 yılları arasında toplam 200 doktora tezinin hazırlandığ1 tespit edilmiştir. Söz konusu doktora tezlerinden 175 tanesi erişime açıkken 25 tanesi erişime kapalı durumdadır.

Çalışmada ABD'de eğitim yönetimi alanında hazırlanan doktora tezleri için örneklem seçimi yapılmıştır. ABD'de eğitim yönetimi alanında hazırlanan doktora tezlerinin belirlenmesinde tabakalı örnekleme ile basit tesadüfi örnekleme yöntemleri kullanılmıştır. Tabakalı örnekleme yöntemi, hazırlanan doktora tezlerinin çalışmaya yıllar içerisinde hazırlanan tez sayıları ile orantılı olacak şekilde etki edebilmesi için tercih edilmiştir. Çalışmaya dahil edilecek tezlerin rasgele belirlenebilmesi için ise basit tesadüfi örnekleme yöntemi kullanılmıştır. ProQuest veri tabanında yapılan taramalar sonucunda ABD'de eğitim yönetimi alanında 2014-2018 yılları arasında toplam 1476 doktora tezinin hazırlandığ1 tespit edilmiştir. \%95 güven düzeyi için araştırmanın örneklemi 306 olarak belirlenmiştir. Ancak, yapılan çalışmanın geçerlik ve güvenirliğini arttırabilmek adına örnekleme 339 doktora tezi dâhil edilmiştir. Tabakalı örnekleme yöntemi ile yapılan hesaplamada hangi yıldan kaç adet doktora tezinin çalışmaya dâhil edileceği tespit edilmiştir. Son olarak çalışmaya dâhil edilecek tezlerin belirlenmesinde basit tesadüfi örnekleme yönteminden yararlanılmıştır. Yapılan taramalarda tam metin halinde erişilebilen doktora tezleri çalışma kapsamına dâhil edilmiştir.

\section{Veri Toplama Araçları}

Akademik Yayın Değerlendirme Formu. Çalışmada kullanılan veri toplama aracı araştırmacı tarafindan geliştirilmiştir. Veri toplama aracının geliştirilmesi için ilgili alanyazın ve bu konu ile ilgili yapılmış çalışmalar taranmıştır. Özelde ise eğitim bilimleri araştırmalarını değerlendirmek amacıyla geliştirilen ölçekler ve yapılmış çalışmalar (Karadağ, 2009; Uysal, 2013) incelenmiştir. Elde edilen veriler doğrultusunda geliştirilen Akademik Yayın Değerlendirme Formu demografik özellikler, konu, yöntem ve öneriler olmak üzere dört boyuttan oluşmaktadır. Söz konusu dört boyut ise demografik özellikler; y1l, üniversite, enstitü; konu; yöntem; araştırma yöntemi, araştırma modeli, örneklem türü, örnekleme yöntemi, veri toplama aracı, geçerlik-güvenirlik çalışmaları, istatistiki teknikler; öneriler; araştırmacılara yönelik öneriler, uygulayıcılara yönelik öneriler alt boyutlarından oluşmaktadır.

Yapılan taramalar sonunda geliştirilen akademik yayın değerlendirme formunun geçerlik ve güvenirliği için alan uzmanlarının görüşleri alınmıştır. Bu işlem için eğitim yönetimi (3 öğretim üyesi) ve eğitimde ölçme değerlendirme (2 öğretim üyesi) anabilim dallarında görev yapmakta olan uzmanların görüşleri alınmıştır. Yapılan geri bildirimler doğrultusunda gerekli görülen düzenlemeler yapılmış ve akademik yayın değerlendirme formuna son hali verilmiştir.

\section{Verilerin Analizi}

Araştırma kapsamında elde edilen veriler, nitel araştırma yöntemi olan içerik analizi türlerinden kategorisel analiz ve frekans analizi teknikleri ile çözümlenmiştir. İçerik analizi, belli bir anlam çıkarma çabasıyla belirli veri grubunun dikkatli, ayrıntılı ve sistematik bir biçimde incelenerek yorumlanmasıdır. 
İçerik analizi sosyoloji, psikoloji, eğitim, işletme, sanat ve politik bilimler gibi birçok disiplinde kullanılmaktadır. İçerik analizi, kısaca, bir kodlama işlemi ve veri yorumlama sürecidir (Şentuna-Akay, 2019, s.343-345). İçerik analizi ile araştırmacılar sahip oldukları verileri tanımlamaya, verilerin içindeki saklı gerçekleri ortaya çıkarmaya gayret ederler. İçerik analizi yardımıyla yapılan işlem, birbirine benzeyen verileri belirli kavramlar ve temalar çerçevesinde bir araya getirmek ve bunları okuyucunun anlayabileceği bir şekilde düzenleyerek yorumlamaktır (Yıldırım ve Şimşek, 2008, s.227).

Kategorisel analiz, genel olarak, belirli bir mesajın önce birimlere bölünmesi ve bu birimlerin önceden saptanmış ölçütlere göre kategoriler halinde gruplandırılmasını ifade etmektedir (Tavşancıl ve Aslan, 2001, s. 90). Kategorisel analiz süreci; (1) verilerin kodlanması, (2) kategorilerin oluşturulması, (3) kategorilerin düzenlenmesi ve (4) bulguların tanımlanması ve yorumlanması işlemlerini içermektedir (Corbin ve Strauss, 2008, s. 85). Öncelikle araşturmaya dâhil edilen doktora tezleri geliştirilen veri toplama aracına göre veri kodlaması işlemine tabi tutulmuştur. Elde edilen veriler ışığında kategoriler oluşturulmuş ve kategoriler düzenlendikten sonra yorumlama işlemi yapılmışır. Araştırma kapsamında model, örneklem grubu, örneklem büyüklüğü, örnekleme yöntemi, çözümleme yöntemi ve demografik özellikler gibi değişkenlerin çözümlenmesinde ise frekans analizi kullanılmışıtır.

\section{Bulgular}

Bu bölümde Türkiye ve ABD'de eğitim yönetimi alanında hazırlanan doktora tezlerinin "yll, üniversite, enstitü, konu, araştırma yöntemi, araştırma modeli, örneklem türü, örnekleme yöntemi, veri toplama arac1, geçerlik-güvenirlik çalışmaları, istatistiki teknikler, araştırmacılara yönelik öneriler ve uygulayıcılara yönelik öneriler" başlıkları altında incelenmesi sonucunda elde edilen bulgulara yer verilmiştir. Türkiye'de eğitim yönetimi alanında hazırlanan doktora tezlerinin hazırlandıkları yıla göre dağılıma ilişkin verilere Tablo 1'de yer verilmiştir.

Tablo 1. Türkije'de Eğitim Yönetimi Alannda Hazurlanan Doktora Tęllerinin Yıllara Göre Dağgllımı

\begin{tabular}{ccccc}
\hline Yll & Erişim Durumu (Açı) & Erisiom Durumu (Kapali) & $\boldsymbol{n}$ & \% \\
\hline 2014 & 26 & 0 & 26 & 13.0 \\
2015 & 32 & 0 & 32 & 16.0 \\
2016 & 46 & 0 & 46 & 23.0 \\
2017 & 33 & 21 & 54 & 27.0 \\
2018 & 38 & 4 & 42 & 21.0 \\
\hline Toplam & 175 & 25 & 200 & 100 \\
\hline
\end{tabular}

Tablo 1'de de görüldüğü üzere Türkiye'de eğitim yönetimi alanında hazırlanan doktora tezlerinin sayıs1 $2014(\mathrm{n}=26)$ yllından $2017(\mathrm{n}=54)$ y1lına kadar artış gösterirken $2018(\mathrm{n}=42)$ y1lında hazırlanan doktora tezlerinin sayısında bir önceki ylla göre düşüş meydana gelmiştir. Beş yll içerisinde eğitim yönetimi alanında hazırlanan doktora tezleri göz önüne alındığında \%27.0 oranla 2017 ( $\mathrm{n}=54)$ yllında hazırlanan doktora tez sayısı en fazla orana sahiptir.

Tablo 2'de ABD'de eğitim yönetimi alanında hazırlanan doktora tezlerinin hazırlandıkları yıla göre dağılıma ilişkin verilere yer verilmiştir.

Tablo 2. ABD'de Eğitim Yönetimi Alannda Hažrlanan Doktora Tezlerinin Yullara Göre Dağllamı

\begin{tabular}{|c|c|c|c|c|}
\hline$Y 11$ & Tez Say1s1 & Örneklem Sayısı & Örnekleme Alınan & $\%$ \\
\hline 2014 & 323 & $(323 / 1476) * 306=67$ & 75 & 21.9 \\
\hline 2015 & 297 & $(297 / 1476) * 306=62$ & 70 & 20.1 \\
\hline 2016 & 313 & $(313 / 1476) * 306=65$ & 72 & 21.2 \\
\hline 2017 & 286 & $(286 / 1476) * 306=59$ & 64 & 19.4 \\
\hline 2018 & 257 & $(257 / 1476) * 306=53$ & 58 & 17.4 \\
\hline Toplam & 1476 & 306 & 339 & 100 \\
\hline
\end{tabular}

Tablo 2'de de görüldüğü üzere ABD'de eğitim yönetimi alanında hazırlanan doktora tezlerinin sayısında yıllar arasında dalgalanmalar görülmektedir. Bazı yıllar tez sayılarında artış meydana gelirken bazı yıllarda düşüş yaşanmıştır. 2014-2018 yılları arasında ABD'de eğitim yönetimi alanında en fazla tez 2014 ( $\mathrm{n}=323, \% 21.9)$ yilında hazırlanmıştır.

Tablo 3'te Türkiye'de eğitim yönetimi alanında hazırlanan doktora tezlerinin hazırlandıkları üniversiteye göre dağllıma ilişkin verilere yer verilmiştir. 
Tablo 3. Türkiye'de Eğitim Yönetimi Alanında Hazırlanan Doktora Tezlerinin Üniversitelere Göre Dağllımı

\begin{tabular}{|c|c|c|c|c|c|c|c|}
\hline Üniversiteler & 2014 & 2015 & 2016 & 2017 & 2018 & $n$ & $\%$ \\
\hline Eskişehir Osmangazi Üniversitesi & 4 & 9 & 4 & 2 & 6 & 25 & 14.3 \\
\hline Ankara Üniversitesi & 4 & 3 & 9 & 3 & 5 & 24 & 13.7 \\
\hline Hacettepe Üniversitesi & 1 & 5 & 7 & 6 & 3 & 22 & 12.6 \\
\hline Marmara Üniversitesi & 2 & 2 & 2 & 4 & 3 & 13 & 7.4 \\
\hline Gazi Üniversitesi & 3 & 3 & 3 & 3 & - & 12 & 6.9 \\
\hline Abant İzzet Baysal Üniversitesi & 3 & 1 & 3 & 4 & - & 11 & 6.3 \\
\hline Çanakkale 18 Mart Üniversitesi & 2 & 3 & 3 & 2 & 1 & 11 & 6.3 \\
\hline İnönü Üniversitesi & - & - & 5 & 2 & 4 & 11 & 6.3 \\
\hline Akdeniz Üniversitesi & - & 1 & 4 & 2 & 2 & 9 & 5.1 \\
\hline Anadolu Üniversitesi & - & - & 3 & 1 & 1 & 5 & 2.9 \\
\hline Pamukkale Üniversitesi & 2 & 1 & - & 1 & 1 & 5 & 2.9 \\
\hline Atatürk Üniversitesi & 1 & 2 & 1 & - & - & 4 & 2.3 \\
\hline Dokuz Eylül Üniversitesi & 2 & - & 1 & - & 1 & 4 & 2.3 \\
\hline Dicle Üniversitesi & 1 & 1 & 1 & - & - & 3 & 1.7 \\
\hline Ege Üniversitesi & 1 & 1 & - & - & 1 & 3 & 1.7 \\
\hline Fırat Üniversitesi & - & - & 1 & 2 & - & 3 & 1.7 \\
\hline Gaziantep Üniversitesi & - & - & - & 1 & 2 & 3 & 1.7 \\
\hline Kocaeli Üniversitesi & - & - & 1 & 1 & 1 & 3 & 1.7 \\
\hline Orta Doğu Teknik Üniversitesi & - & - & - & - & 2 & 2 & 1.1 \\
\hline İstanbul Sabahattin Zaim Üniversitesi & - & - & - & - & 1 & 1 & 0.6 \\
\hline Necmettin Erbakan Üniversitesi & - & - & 1 & - & - & 1 & 0.6 \\
\hline Toplam & & & & & & 175 & 100 \\
\hline
\end{tabular}

Tablo 3'te de görüldüğü üzere Türkiye'de eğitim yönetimi alanında hazırlanan doktora tezlerinin 21 farklı üniversite bünyesinde hazırlandığı görülmektedir. Araştırma kapsamında değerlendirmeye alınan doktora tezlerinin \%14.3'ü Eskişehir Osmangazi Üniversitesi $(n=25)$ bünyesinde hazırlanmıştır. Eskişehir Osmangazi Üniversitesini sirasıly; \%13.7 oran ile Ankara Üniversitesi $(n=24), \% 12.6$ oran ile Hacettepe Üniversitesi $(n=22), \% 7.4$ oran ile Marmara Üniversitesi $(n=13)$ ve \%6.9 oran ile Gazi Üniversitesi $(n=12)$ takip etmektedir. Tablo 4'te ABD'de eğitim yönetimi alanında hazırlanan doktora tezlerinin hazırlandıkları üniversiteye göre dağılıma ilişkin verilere yer verilmiştir.

Tablo 4. ABD'de Eğitim Yönetimi Alanında Hazırlanan Doktora Tezlerinin Üniversitelere Göre Dağllımı

\begin{tabular}{|c|c|c|c|c|c|c|c|}
\hline Üniversiteler & 2014 & 2015 & 2016 & 2017 & 2018 & $n$ & $\%$ \\
\hline University of South Dakota & 20 & 4 & 11 & 7 & 13 & 55 & 16.2 \\
\hline Illinois State University & 16 & 13 & 10 & 6 & 1 & 46 & 13.6 \\
\hline Texas A\&M University & 7 & 14 & 5 & - & 8 & 34 & 10.0 \\
\hline University of Nebraska at Omaha & 3 & 6 & 8 & 10 & 7 & 34 & 10.0 \\
\hline University of South Carolina & 9 & 9 & 8 & 5 & 1 & 32 & 9.4 \\
\hline University of the Pacific & 7 & 8 & 6 & - & 6 & 27 & 8.0 \\
\hline University of Nebraska - Lincoln & 2 & 4 & 7 & 3 & 6 & 22 & 6.5 \\
\hline Michigan State University & 3 & 5 & 3 & 3 & 4 & 18 & 5.3 \\
\hline North Carolina State University & 1 & 3 & 3 & 6 & 3 & 16 & 4.7 \\
\hline University at Albany, State University of New York & 3 & 3 & 7 & - & - & 13 & 3.8 \\
\hline University of Southern Mississippi & - & - & 1 & 6 & 3 & 10 & 2.9 \\
\hline St. John's University & - & - & - & 7 & - & 7 & 2.1 \\
\hline Florida International University & 1 & - & 1 & - & - & 2 & 0.6 \\
\hline Loyola University & - & - & - & 2 & - & 2 & 0.6 \\
\hline New Mexico State University & - & - & - & 2 & - & 2 & 0.6 \\
\hline Portland State University & - & - & - & 2 & - & 2 & 0.6 \\
\hline Southern Illinois University & 1 & - & - & - & 1 & 2 & 0.6 \\
\hline The University of Texas at El Paso & - & - & - & 1 & 1 & 2 & 0.6 \\
\hline University of New Orleans & - & 1 & 1 & - & - & 2 & 0.6 \\
\hline Drexel University & - & - & 1 & - & - & 1 & 0.3 \\
\hline George Washington University & - & - & - & - & 1 & 1 & 0.3 \\
\hline Marian University & - & - & - & 1 & - & 1 & 0.3 \\
\hline Pepperdine University & - & - & - & 1 & - & 1 & 0.3 \\
\hline State University of New Jersey & - & - & - & - & 1 & 1 & 0.3 \\
\hline Tennessee State University & - & - & - & - & 1 & 1 & 0.3 \\
\hline University of Illinois at Urbana-Champaign & - & - & - & 1 & - & 1 & 0.3 \\
\hline University of Minnesota & - & - & - & - & 1 & 1 & 0.3 \\
\hline University of Missouri-Kansas City & 1 & - & - & - & - & 1 & 0.3 \\
\hline University of Toledo & 1 & - & - & - & - & 1 & 0.3 \\
\hline Walden University & - & - & - & 1 & - & 1 & 0.3 \\
\hline Toplam & & & & & & 339 & 100 \\
\hline
\end{tabular}


Tablo 4'te de görüldüğü üzere ABD'de eğitim yönetimi alanında hazırlanan doktora tezlerinin 30 farklı üniversite bünyesinde hazırlandığı görülmektedir. Araştırma kapsamında değerlendirmeye alınan doktora tezlerinin \%16.2'si University of South Dakota $(n=55)$ bünyesinde hazırlanmıştır. University of South Dakota'yı sırasiyla; \%13.6 oran ile Illinois State University $(n=46), \% 10.0$ oran ile Texas A\&M University ( $\mathrm{n}=34)$ ve University of Nebraska at Omaha $(\mathrm{n}=34)$ ve $\% 9.4$ oran ile University of South Carolina ( $\mathrm{n}=32)$ takip etmektedir.

Tablo 5'te Türkiye'de eğitim yönetimi alanında hazırlanan doktora tezlerinin hazırlandıkları enstitüye göre dağılıma ilişkin verilere yer verilmiştir.

Tablo 5. Türkiye'de Eğitim Yönetimi Alanında Hažrlanan Doktora Tezllerinin Enstitülere Göre Dağıllam

\begin{tabular}{cccccccc}
\hline Enstitü & $\mathbf{2 0 1 4}$ & $\mathbf{2 0 1 5}$ & $\mathbf{2 0 1 6}$ & $\mathbf{2 0 1 7}$ & $\mathbf{2 0 1 8}$ & $\boldsymbol{n}$ & $\boldsymbol{\%}$ \\
\hline Eğitim Bilimleri Enstitüsü & 25 & 31 & 45 & 32 & 33 & 166 & 94.9 \\
Sosyal Bilimler Enstitüsü & 1 & 1 & 1 & 1 & 5 & 9 & 5.1 \\
\hline Toplam & & & & & & 175 & 100 \\
\hline
\end{tabular}

Tablo 5’te de görüldüğü üzere Türkiye'de eğitim yönetimi alanında hazırlanan doktora tezlerinin \%94.9'unun eğitim bilimleri enstitüsü $(n=166)$ bünyesinde, \%5.1'inin ise sosyal bilimler enstitüsü $(n=9)$ bünyesinde hazırlandığ1 görülmektedir. Sosyal bilimler enstitüsü bünyesinde eğitim yönetimi doktora eğitimi veren üniversiteler Ege Üniversitesi, İstanbul Sabahattin Zaim Üniversitesi, Kocaeli Üniversitesi ve Orta Doğu Teknik Üniversitesi'dir. ABD'de hazırlanan doktora tezlerinde enstitü ayrımı gözetilmediği için tezler enstitü dağllımına göre değerlendirilmemiştir.

Tablo 6'da Türkiye'de eğitim yönetimi alanında hazırlanan doktora tezlerinin çalşılan konulara göre dağıllıma ilişkin verilere yer verilmiştir.

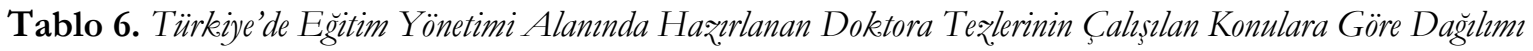

\begin{tabular}{lccccccc}
\hline \multicolumn{1}{c}{ Konu } & 2014 & 2015 & 2016 & 2017 & 2018 & $\boldsymbol{n}$ & \% \\
\hline Örgüt ve Örgütsel Davranış & 30 & 27 & 29 & 25 & 29 & 140 & 80.0 \\
Yönetim & 14 & 17 & 30 & 14 & 19 & 94 & 53.7 \\
Liderlik & 6 & 9 & 9 & 8 & 11 & 43 & 24.6 \\
Eğitim Politikaları & 2 & 7 & 9 & 6 & 4 & 28 & 16.0 \\
Eğitim Psikolojisi & 5 & 3 & 6 & 3 & 10 & 27 & 15.4 \\
Eğitim Ekonomisi & 3 & 2 & 1 & - & 1 & 7 & 4.0 \\
Ĕgitim Yönetiminde Yeni Yaklaşımlar & - & 1 & 3 & - & 2 & 6 & 3.4 \\
\hline
\end{tabular}

Tablo 6'da da görüldügüu üzere Türkiye'de eğitim yönetimi alanında hazırlanan doktora tezlerinde en çok çalışlan konunun \%80.0 oran ile örgüt ve örgütsel davranış $(n=140)$ olduğu görülmektedir. Örgüt ve örgütsel davranış konularını sırasıyla \%53.7 oran ile yönetim $(n=94)$ ve $\% 24.6$ oran ile liderlik $(n=43)$ konuları takip etmektedir. Türkiye'de eğitim yönetimi alanında hazırlanan doktora tezlerinde en az çalısılan konular ise $\% 4.0$ oran ile eğitim ekonomisi $(n=7)$ ve $\% 3.4$ oran ile eğitim yönetiminde yeni yaklaşımlar $(\mathrm{n}=6)$ konularıdır.

Tablo 7'de ABD'de eğitim yönetimi alanında hazırlanan doktora tezlerinin çalsşılan konulara göre dağıllıma ilişkin verilere yer verilmiştir.

Tablo 7. ABD’de Eğitim Yönetimi Alanmda Hažrlanan Doktora Tezlerinin Çalşslan Konulara Göre Dağğllmı

\begin{tabular}{lccccccc}
\hline \multicolumn{1}{c}{ Konu } & 2014 & 2015 & 2016 & 2017 & 2018 & $\boldsymbol{n}$ & \% \\
\hline Örgüt ve Örgütsel Davranış & 44 & 43 & 37 & 37 & 37 & 198 & 58.4 \\
Yönetim & 34 & 41 & 29 & 30 & 25 & 159 & 46.9 \\
Ë̆itim Politikaları & 11 & 8 & 20 & 14 & 13 & 66 & 19.5 \\
Liderlik & 8 & 6 & 12 & 8 & 10 & 44 & 13.0 \\
Eğitim Ekonomisi & 5 & 6 & 1 & 1 & 4 & 17 & 5.0 \\
Eğitim Psikolojisi & 4 & 4 & 1 & 3 & 1 & 13 & 3.8 \\
Ĕgitim Yönetiminde Yeni Yaklaşımlar & 1 & 3 & - & - & 1 & 5 & 1.5 \\
\hline
\end{tabular}

Tablo 7'de de görüldüğ̈ üzere ABD'de eğitim yönetimi alanında hazırlanan doktora tezlerinde en çok çalış1lan konunun \%58.4 oran ile örgüt ve örgütsel davranış $(n=198)$ olduğu görülmektedir. Örgüt ve örgütsel davranış konularını sırasıyla $\% 46.9$ oran ile yönetim $(n=159)$ ve $\% 19.5$ oran ile eğitim politikaları ( $\mathrm{n}=66)$ konuları takip etmektedir. ABD'de eğitim yönetimi alanında hazırlanan doktora tezlerinde en az çalsşlan konular ise $\% 3.8$ oran ile eğitim psikolojisi $(n=13)$ ve $\% 1.5$ oran ile eğitim yönetiminde yeni yaklaşımlar $(\mathrm{n}=5)$ konularıdır. 
Tablo 8'de Türkiye'de eğitim yönetimi alanında hazırlanan doktora tezlerinin kullanılan araştırma yöntemine göre dağılıma ilişkin verilere yer verilmiştir.

Tablo 8. Türkiye'de Eğitim Yönetimi Alanında Haz̧ılanan Doktora Teqlerinin Kullanlan Araştırma Yöntemine Göre Dağılımı

\begin{tabular}{|c|c|c|c|c|c|c|c|}
\hline Yöntem & 2014 & 2015 & 2016 & 2017 & 2018 & $n$ & $\%$ \\
\hline Nicel & 20 & 17 & 11 & 17 & 15 & 80 & 45.7 \\
\hline Karma & 1 & 7 & 19 & 10 & 12 & 49 & 28.0 \\
\hline Nitel & 5 & 8 & 16 & 6 & 11 & 46 & 26.3 \\
\hline Toplam & & & & & & 175 & 100 \\
\hline
\end{tabular}

Tablo 8'de de görüldüğü üzere Türkiye'de eğitim yönetimi alanında hazırlanan doktora tezlerinde en çok kullanılan araştırma yönteminin $\% 45.7$ oran ile nicel $(n=80)$ araştırma yöntemi olduğu görülmektedir. Nicel araştırma yöntemini sırasıyla \%28.0 oran ile karma $(n=49)$ araştırma yöntemi ve $\% 26.3$ oran ile nitel (n=46) araştırma yöntemi takip etmektedir.

Tablo 9'da ABD’de eğitim yönetimi alanında hazırlanan doktora tezlerinin kullanılan araştırma yöntemine göre dağılıma ilişkin verilere yer verilmiştir.

Tablo 9. ABD'de Ë̆itim Yönetimi Alanında Hažrlanan Doktora Tezlerinin Kullanılan Araștırma Yöntemine Göre Dă̆llım

\begin{tabular}{|c|c|c|c|c|c|c|c|}
\hline Yöntem & 2014 & 2015 & 2016 & 2017 & 2018 & $n$ & $\%$ \\
\hline Nitel & 27 & 40 & 41 & 34 & 33 & 175 & $\overline{51.6}$ \\
\hline Nicel & 39 & 24 & 25 & 21 & 17 & 126 & 37.2 \\
\hline Karma & 9 & 6 & 6 & 9 & 8 & 38 & 11.2 \\
\hline Toplam & & & & & & 339 & 100 \\
\hline
\end{tabular}

Tablo 9'da da görüldüğü üzere ABD'de eğitim yönetimi alanında hazırlanan doktora tezlerinde en çok kullanılan araştırma yönteminin \%51.6 oran ile nitel $(n=175)$ araştırma yöntemi olduğu görülmektedir. Nitel araştırma yöntemini sırasıly \%37.2 oran ile nicel $(n=126)$ araştırma yöntemi ve \%11.2 oran ile karma (n=38) araştırma yöntemi takip etmektedir.

Tablo 10'da Türkiye'de eğitim yönetimi alanında hazırlanan doktora tezlerinin kullanılan araştırma modeline göre dağılıma ilişkin verilere yer verilmiştir.

Tablo 10. Türkiye'de Eğ̈itim Yönetimi Alanında Hazırlanan Doktora Tezlerinin Kullanlan Araştırma Modeline Göre Dă̆llımı

\begin{tabular}{|c|c|c|c|c|c|c|c|}
\hline Araştırma Modeli & 2014 & 2015 & 2016 & 2017 & 2018 & $n$ & $\%$ \\
\hline Tarama & 24 & 27 & 33 & 23 & 25 & 132 & 75.4 \\
\hline İlişkisel & 11 & 14 & 14 & 16 & 16 & 71 & 40.6 \\
\hline Durum Analizi & 1 & 4 & 17 & 4 & 8 & 34 & 19.4 \\
\hline Olgu Bilim & - & 1 & 10 & 7 & 9 & 27 & 15.4 \\
\hline Nedensel & - & - & 2 & 5 & 2 & 9 & 5.1 \\
\hline Kuram Oluşturma & - & 1 & 1 & 1 & 1 & 4 & 2.3 \\
\hline Deneysel & - & - & - & 1 & 2 & 3 & 1.7 \\
\hline Örnek Olay & - & - & - & 1 & 1 & 2 & 1.2 \\
\hline Etnografik & - & 1 & - & - & - & 1 & 0.6 \\
\hline Eylem Araştırması & - & - & - & - & 1 & 1 & 0.6 \\
\hline Kültür Analizi & - & - & - & - & 1 & 1 & 0.6 \\
\hline
\end{tabular}

Tablo 10'da da görüldüğü üzere Türkiye'de eğitim yönetimi alanında hazırlanan doktora tezlerinde en çok kullanılan araştırma modelinin \%75.4 oran ile tarama $(n=132)$ modeli olduğu görülmektedir. Tarama modelini sırasıyla \%40.6 oran ile ilişkisel $(n=71)$ model ve \%19.4 oran ile durum analizi ( $n=34)$ modeli takip etmektedir. Türkiye'de eğitim yönetimi alanında hazırlanan doktora tezlerinde en az tercih edilen araştırma modelleri ise kuram oluşturma $(n=4, \% 2.4)$, deneysel $(n=3, \% 1.8)$, örnek olay $(n=2, \% 1.2)$, etnografik $(n=1, \% 0.6)$, eylem araştırması $(n=1, \% 0.6)$ ve kültür analizi $(n=1, \% 0.6)$ modelleridir.

Tablo 11'de ABD'de eğitim yönetimi alanında hazırlanan doktora tezlerinin kullanılan araştırma modeline göre dağılıma ilişkin verilere yer verilmiştir. 
Tablo 11. ABD'de Eğtitim Yönetimi Alanında Hažrlanan Doktora Tę̧lerinin Kullanulan Araștırma Modeline Göre Dağgllm

\begin{tabular}{lccccccc}
\hline \multicolumn{1}{c}{ Arasttirma Modeli } & 2014 & 2015 & 2016 & 2017 & 2018 & n & \% \\
\hline Durum Analizi & 22 & 29 & 31 & 28 & 30 & 140 & 41.3 \\
Tarama & 33 & 17 & 23 & 17 & 17 & 107 & 31.6 \\
Ilişkisel & 22 & 9 & 11 & 13 & 10 & 65 & 19.2 \\
Olgu Bilim & 3 & 10 & 10 & 13 & 9 & 45 & 13.3 \\
Deneysel & 3 & 6 & 2 & 2 & 4 & 17 & 5.0 \\
Etnografik & 1 & 3 & 3 & 1 & - & 8 & 2.4 \\
Odak Grupları & - & 1 & 1 & 3 & 1 & 6 & 1.8 \\
Kuram Oluşturma & 2 & 1 & - & 1 & 1 & 5 & 1.5 \\
Eylem Arastırmasi & 1 & 1 & - & - & - & 2 & 0.6 \\
Kültür Analizi & - & - & 1 & - & - & 1 & 0.3 \\
\hline
\end{tabular}

Tablo 11'de de görüldüğü üzere ABD'de eğitim yönetimi alanında hazırlanan doktora tezlerinde en çok kullanılan araştırma modelinin $\% 41.3$ oran ile durum analizi $(n=140)$ modeli olduğu görülmektedir. Durum analizi modelini sırasıyla \%31.6 oran ile tarama $(n=107)$ modeli ve $\% 19.2$ oran ile ilisskisel $(n=65)$ model takip etmektedir. ABD'de eğitim yönetimi alanında hazırlanan doktora tezlerinde en az tercih edilen araştırma modelleri ise eylem araştırması $(n=2, \% 0.6)$ ve kültür analizi $(n=1, \% 0.3)$ modelleridir.

Tablo 12'de Türkiye'de eğitim yönetimi alanında hazırlanan doktora tezlerinin evren örneklem gruplarına göre dağılıma ilişkin verilere yer verilmiştir.

Tablo 12. Türkiye'de Ë̈̆tim Yönetimi Alanında Hažrlanan Doktora Tezlerinin Kullamlan Evren Örneklem Gruplarnna Göre Dağllam

\begin{tabular}{|c|c|c|c|c|c|c|c|}
\hline Evren-Örneklem & 2014 & 2015 & 2016 & 2017 & 2018 & $n$ & $\%$ \\
\hline Öğretmen & 15 & 15 & 23 & 23 & 22 & 98 & 56.0 \\
\hline Yönetici & 5 & 9 & 21 & 9 & 6 & 50 & 28.6 \\
\hline Diğer* & 5 & 7 & 13 & 7 & 8 & 40 & 22.9 \\
\hline Öğrenci & 6 & 5 & 5 & 8 & 8 & 32 & 18.3 \\
\hline Doküman & 3 & 8 & 9 & 3 & 6 & 29 & 16.6 \\
\hline Öğrenci Velisi & - & 1 & 4 & 2 & 1 & 8 & 4.6 \\
\hline Müfettiş & 1 & - & 3 & - & - & 4 & 2.3 \\
\hline
\end{tabular}

* Bu örneklem grubunda öğretim elemanları, milli eğitim çalş̧anları, çalışanlar, mezun öğrenciler, kursiyerler ve dış paydaşlar yer almaktadır.

Tablo 12 'de de görüldüğü üzere Türkiye'de eğitim yönetimi alanında hazırlanan doktora tezlerinde en çok kullanılan evren-örneklem grubunun \%56.0 oran ile öğretmenler $(\mathrm{n}=98)$ olduğu görülmektedir. Öğretmenlerden oluşan evren-örneklem grubunu sırasıyla \%28.6 oran ile yöneticiler $(n=50)$ ve \%22.9 oran ile diğer $(n=40)$ evren-örneklem grubu takip etmektedir. Türkiye'de eğitim yönetimi alanında hazırlanan doktora tezlerinde üzerinde en az çalışma yapılan evren-örneklem grubunu ise $\% 2.3$ oran ile müfettişler $(\mathrm{n}=4)$ oluşturmaktadır.

Tablo 13'te ABD'de eğitim yönetimi alanında hazırlanan doktora tezlerinin evren örneklem gruplarına göre dağılıma ilişkin verilere yer verilmiştir.

Tablo 13. ABD'de Eğitim Yönetimi Alannda Hažrlanan Doktora Tezৃlerinin Kullanlan Evren Örneklem Gruplarna Göre Dağgllmı

\begin{tabular}{lccccccc}
\hline \multicolumn{1}{c}{ Evren-Örneklem } & 2014 & 2015 & 2016 & 2017 & 2018 & n & \% \\
\hline Yönetici & 36 & 24 & 28 & 29 & 23 & 140 & 41.3 \\
Ö̆ğrenci & 13 & 25 & 27 & 23 & 21 & 109 & 32.2 \\
Öğretmen & 18 & 22 & 19 & 24 & 14 & 97 & 28.6 \\
Doküman & 21 & 11 & 12 & 6 & 7 & 57 & 16.8 \\
Diğer* & 13 & 10 & 9 & 2 & 6 & 40 & 11.8 \\
Öğrenci Velisi & 3 & 8 & 5 & 3 & 4 & 23 & 6.8 \\
Müfettiş & 2 & 1 & 10 & 4 & 1 & 18 & 5.3 \\
\hline
\end{tabular}

* Bu örneklem grubunda öğretim elemanları, milli eğitim çalışanları, çalışanlar, mezun öğrenciler, sağlıkçılar, hastalar, yöneticiler ve mimar yer almaktadir.

Tablo 13’te de görüldüğü üzere ABD'de eğitim yönetimi alanında hazırlanan doktora tezlerinde en çok kullanılan evren-örneklem grubunun $\% 41.3$ oran ile yöneticiler $(n=140)$ olduğu görülmektedir. Yöneticilerden oluşan evren-örneklem grubunu sırasıyla \%32.2 oran ile ögrenciler ( $n=109)$ ve \%28.6 oran ile öğretmenler $(\mathrm{n}=97)$ evren-örneklem grubu takip etmektedir. ABD'de eğitim yönetimi alanında 
hazırlanan doktora tezlerinde üzerinde en az çalışma yapılan evren-örneklem grubunu ise \%5.3 oran ile müfettişler ( $\mathrm{n}=18$ ) oluşturmaktadır.

Tablo 14'te Türkiye'de eğitim yönetimi alanında hazırlanan doktora tezlerinin örnekleme yöntemlerine göre dağıllıma ilişkin verilere yer verilmiştir.

Tablo 14. Türkiye'de Eğitim Yönetimi Alanında Hažrlanan Doktora Tezlerinin Kullanulan Örnekleme Yöntemlerine Göre Dağgllmı

\begin{tabular}{lccccccc}
\hline \multicolumn{1}{c}{ Örnekleme Yöntemi } & 2014 & 2015 & 2016 & 2017 & 2018 & n & \% \\
\hline Amaçlı & 6 & 11 & 21 & 7 & 10 & 55 & 31.4 \\
Tabakalı & 9 & 9 & 16 & 9 & 11 & 54 & 30.9 \\
Basit Tesadüfi & 6 & 5 & 10 & 9 & 4 & 34 & 19.4 \\
Maksimum Çeşitlilik & 2 & 3 & 7 & 4 & 6 & 22 & 12.6 \\
Ölçüt & - & 4 & 7 & 5 & 4 & 20 & 11.4 \\
Küme/Kademeli & 2 & 4 & 3 & 4 & 4 & 17 & 9.7 \\
Kolay Ulaşılabilirlik & 2 & 1 & 1 & 6 & 6 & 16 & 9.1 \\
Kartopu & 2 & 1 & 2 & 4 & 2 & 11 & 6.3 \\
Kota & - & - & - & 1 & - & 1 & 0.6 \\
\hline
\end{tabular}

Tablo 14'te de görüldüğü üzere Türkiye'de eğitim yönetimi alanında hazırlanan doktora tezlerinde en çok kullanılan örnekleme yönteminin \%31.4 oran ile amaçlı $(n=55)$ örnekleme yöntemi olduğu görülmektedir. Amaçlı örnekleme yöntemini sırasıyla, \%30.9 oran ile tabakalı ( $\mathrm{n}=54)$ örnekleme yöntemi ve \%19.4 oran ile basit tesadüfi $(n=34)$ örnekleme yöntemi takip etmektedir. Bununla birlikte, hazırlanan doktora tezlerinde maksimum çeşitlilik, küme/kademeli, ölçüt, kolay ulaşılabilirlik ve kartopu gibi örnekleme yöntemleri de kullanılmıştır. Türkiye'de eğitim yönetimi alanında hazırlanan doktora tezlerinde en az tercih edilen örnekleme yönteminin ise \%0.6 oran ile kota $(n=1)$ örnekleme yöntemi olduğu tespit edilmiştir.

Tablo 15'te ABD'de eğitim yönetimi alanında hazırlanan doktora tezlerinin örnekleme yöntemlerine göre dağıllıma ilişkin verilere yer verilmiştir.

Tablo 15. ABD'de Ë̈itim Yönetimi Alannda Haz̧rlanan Doktora Tęlerinin Kullanlan Örnekleme Yöntemlerine Göre Dağ̊lmı

\begin{tabular}{|c|c|c|c|c|c|c|c|}
\hline Örnekleme Yöntemi & 2014 & 2015 & 2016 & 2017 & 2018 & $\bar{n}$ & $\%$ \\
\hline Amaçlı & 36 & 46 & 43 & 39 & 40 & 204 & 60.2 \\
\hline Basit Tesadüfi & 27 & 17 & 24 & 19 & 13 & 100 & 29.5 \\
\hline Ölçüt & 10 & 4 & 7 & 3 & 2 & 26 & 7.7 \\
\hline Kolay Ulaşılabilirlik & 4 & 2 & 2 & 3 & 4 & 15 & 4.4 \\
\hline Kartopu & 2 & 1 & 4 & 3 & 2 & 12 & 3.5 \\
\hline Maksimum Çeşitlilik & 1 & 1 & 1 & - & 1 & 4 & 1.2 \\
\hline Küme/Kademeli & 2 & - & 1 & - & - & 3 & 0.9 \\
\hline Tabakalı & - & - & - & 1 & - & 1 & 0.3 \\
\hline
\end{tabular}

Tablo 15'te de görüldüğü üzere ABD'de eğitim yönetimi alanında hazırlanan doktora tezlerinde en çok kullanılan örnekleme yönteminin \%60.2 oran ile amaçlı $(\mathrm{n}=204)$ örnekleme yöntemi olduğu görülmektedir. Amaçlı örnekleme yöntemini sırasıyla, \%29.5 oran ile basit tesadüfi $(n=100)$ örnekleme yöntemi ve $\% 7.7$ oran ile ölçüt $(n=26)$ örnekleme yöntemi takip etmektedir. Bununla birlikte, hazırlanan doktora tezlerinde kolay ulaşılabilirlik, kartopu, maksimum çeşitlilik ve küme/kademeli gibi örnekleme yöntemleri de kullanılmıştır. ABD'de eğitim yönetimi alanında hazırlanan doktora tezlerinde en az tercih edilen örnekleme yönteminin ise $\% 0.3$ oran ile tabakalı $(n=1)$ örnekleme yöntemi olduğu tespit edilmiştir.

Tablo 16'da Türkiye'de eğitim yönetimi alanında hazırlanan doktora tezlerinin veri toplama araçlarına göre dağllıma ilişkin verilere yer verilmiştir.

Tablo 16. Türkiye'de Eğitim Yönetimi Alannnda Hažrlanan Doktora Tezlerinin Veri Toplama Araçlarna Göre Dă̆gllm

\begin{tabular}{|c|c|c|c|c|c|c|c|}
\hline Veri Toplama Arac1 & 2014 & 2015 & 2016 & 2017 & 2018 & $n$ & $\%$ \\
\hline Ölçek & 18 & 22 & 24 & 22 & 27 & 113 & 64.6 \\
\hline Görüşme Formu & 4 & 10 & 28 & 16 & 21 & 79 & 45.1 \\
\hline Anket & 5 & 2 & 6 & 5 & 1 & 19 & 10.9 \\
\hline Gözlem Formu & - & 2 & 5 & 1 & 2 & 10 & 5.7 \\
\hline Başarı Testi & - & 1 & - & - & - & 1 & 0.6 \\
\hline Yok & 1 & 4 & 3 & 2 & 2 & 12 & 6.9 \\
\hline
\end{tabular}


Tablo 16'da da görüldüğü üzere Türkiye'de eğitim yönetimi alanında hazırlanan doktora tezlerinde en çok kullanılan veri toplama aracının \%64.6 oran ile ölçek ( $n=113)$ olduğu görülmektedir. Ölçekten sonra en çok tercih edilen veri toplama aracı ise \%45.1 oran ile görüşme formu $(\mathrm{n}=79)$ olmuştur. Türkiye'de eğitim yönetimi alanında hazırlanan doktora tezlerinde en az tercih edilen veri toplama aracı ise $\% 0.6$ oran ile başarı testidir $(\mathrm{n}=1)$. Bununla birlikte Türkiye'de eğitim yönetimi alanında hazırlanan doktora tezlerinin $\% 6.9$ 'unda $(\mathrm{n}=12)$ herhangi bir veri toplama aracı kullanılmamıştır.

Tablo 17'de ABD'de eğitim yönetimi alanında hazırlanan doktora tezlerinin veri toplama araçlarına göre dağılıma ilişkin verilere yer verilmiştir.

Tablo 17. ABD'de Eğitim Yönetimi Alannda Hažrlanan Doktora Tezlerinin Veri Toplama Araçlarna Göre Dağgllım

\begin{tabular}{lccccccc}
\hline \multicolumn{1}{c}{ Veri Toplama Arac1 } & $\mathbf{2 0 1 4}$ & $\mathbf{2 0 1 5}$ & $\mathbf{2 0 1 6}$ & $\mathbf{2 0 1 7}$ & $\mathbf{2 0 1 8}$ & $\boldsymbol{n}$ & $\boldsymbol{\%}$ \\
\hline Görüşme Formu & 31 & 44 & 43 & 41 & 40 & 199 & 58.7 \\
Anket & 24 & 8 & 16 & 11 & 13 & 72 & 21.2 \\
Ölçek & 14 & 10 & 14 & 11 & 5 & 54 & 15.9 \\
Gözlem Formu & 4 & 15 & 8 & 8 & 7 & 42 & 12.4 \\
Başar1 Testi & 5 & 5 & 3 & 3 & 5 & 21 & 6.2 \\
Yok & 14 & 7 & 6 & 4 & 5 & 36 & 10.6 \\
\hline
\end{tabular}

Tablo 17'de de görüldüğü üzere ABD'de eğitim yönetimi alanında hazırlanan doktora tezlerinde en çok kullanılan veri toplama aracının \%58.7 oran ile görüşme formu ( $\mathrm{n}=199)$ olduğu görülmektedir. Görüşme formundan sonra en çok tercih edilen veri toplama arac1 ise $\% 21.2$ oran ile anket $(n=72)$ olmuştur. Yaygın olarak kullanılan veri toplama araçlarından biri olan ölçek ise \%15.9 $(n=54)$ oran ile üçüncü sırada yer almıştır. ABD'de eğitim yönetimi alanında hazırlanan doktora tezlerinde en az tercih edilen veri toplama aracı ise $\% 6.2$ oran ile başarı testidir $(n=21)$. Bununla birlikte ABD'de eğitim yönetimi alanında hazırlanan doktora tezlerinin \%10.6'sında $(\mathrm{n}=36)$ herhangi bir veri toplama aracı kullanılmamıştır.

Tablo 18'de Türkiye'de eğitim yönetimi alanında hazırlanan doktora tezlerinin geçerlik-güvenirlik çalışmalarına göre dağılıma ilişskin verilere yer verilmiştir.

Tablo 18. Türkiye'de Eğitim Yönetimi Alannda Hą̧rlanan Doktora Tezlerinin Geģerlik-Güvenirlik Çalssmalarna Göre Dă̆glımı

\begin{tabular}{|c|c|c|c|c|c|c|c|}
\hline Geçerlik-Güvenirlik Bilgisi & 2014 & 2015 & 2016 & 2017 & 2018 & $n$ & $\%$ \\
\hline Var - Yeterli & 17 & 20 & 23 & 24 & 28 & 112 & 64.0 \\
\hline Var - Kismen Yeterli & 7 & 4 & 12 & 3 & 5 & 31 & 17.7 \\
\hline Var - Yetersiz & 1 & 5 & 10 & 4 & 3 & 23 & 13.2 \\
\hline Yok & 1 & 3 & 1 & 2 & 2 & 9 & 5.1 \\
\hline Toplam & & & & & & 175 & 100 \\
\hline
\end{tabular}

Tablo 18'de de görüldüğü üzere Türkiye'de eğitim yönetimi alanında hazırlanan doktora tezlerinin \%64.0'inda ( $\mathrm{n=112}$ ) geçerlik-güvenirlik bilgilerinin yeterli düzeyde var olduğu görülmektedir. Türkiye'de eğitim yönetimi alanında hazırlanan doktora tezlerinin \%17.7'sinde $(n=31)$ ise verilen geçerlik-güvenirlik bilgilerinin kısmen yeterli düzeyde olduğu; \%13.2'sinde $(n=23)$ ise verilen geçerlik-güvenirlik bilgilerinin yetersiz düzeyde olduğu tespit edilmiştir. Türkiye'de eğitim yönetimi alanında hazırlanan doktora tezlerinin $\% 5.1$ 'inde $(n=9)$ ise herhangi bir geçerlik-güvenirlik bilgisine rastlanmamıştır.

Tablo 19'da ABD'de eğitim yönetimi alanında hazırlanan doktora tezlerinin geçerlik-güvenirlik çalışmalarına göre dağılıma ilişkin verilere yer verilmiştir.

Tablo 19. ABD'de Eğitim Yönetimi Alannda Hą̧rlanan Doktora Tę̧lerinin Geşerlik-Güvenirlik Çalısmalarna Göre Dağ̊lmı

\begin{tabular}{|c|c|c|c|c|c|c|c|}
\hline Geçerlik-Güvenirlik Bilgisi & 2014 & 2015 & 2016 & 2017 & 2018 & $n$ & $\%$ \\
\hline Var-Kısmen Yeterli & 28 & 47 & 44 & 42 & 31 & 192 & 56.6 \\
\hline Var - Yeterli & 13 & 11 & 9 & 13 & 5 & 51 & 15.1 \\
\hline Var-Yetersiz & 4 & 5 & 13 & 5 & 8 & 35 & 10.3 \\
\hline Yok & 30 & 7 & 6 & 4 & 14 & 61 & 18.0 \\
\hline Toplam & & & & & & 339 & 100 \\
\hline
\end{tabular}

Tablo 19'da da görüldüğü üzere ABD'de eğitim yönetimi alanında hazırlanan doktora tezlerinin \%56.6'sında ( $\mathrm{n}=192)$ geçerlik-güvenirlik bilgilerinin kısmen yeterli düzeyde var olduğu görülmektedir. ABD'de eğitim yönetimi alanında hazırlanan doktora tezlerinin $\% 15.1$ 'inde $(\mathrm{n}=51)$ ise verilen geçerlik- 
güvenirlik bilgilerinin yeterli düzeyde olduğu; \%10.3’ünde $(n=35)$ ise verilen geçerlik-güvenirlik bilgilerinin yetersiz düzeyde olduğu tespit edilmiştir. ABD'de eğitim yönetimi alanında hazırlanan doktora tezlerinin \%18.0'1nda ( $\mathrm{n}=61)$ ise herhangi bir geçerlik-güvenirlik bilgisine rastlanmamıştır.

Tablo 20'de Türkiye'de eğitim yönetimi alanında hazırlanan doktora tezlerinin kullanılan istatistiksel tekniklere göre dağılıma ilişkin verilere yer verilmiştir.

Tablo 20. Türkiye'de Eğitim Yönetimi Alannda Hažrlanan Doktora Tezlerinin Kullanulan İstatistiksel Tekniklere Göre Dağgllmı

\begin{tabular}{|c|c|c|c|c|c|c|c|}
\hline Ístatistiksel Teknik & 2014 & 2015 & 2016 & 2017 & 2018 & $n$ & $\%$ \\
\hline Betimsel & 26 & 25 & 44 & 31 & 35 & 161 & 92.0 \\
\hline Diğger* & 12 & 16 & 38 & 20 & 29 & 115 & 65.7 \\
\hline t-testi & 14 & 16 & 21 & 19 & 21 & 91 & 52.0 \\
\hline Anova & 14 & 14 & 19 & 19 & 18 & 84 & 48.0 \\
\hline Faktör Analizi & 4 & 14 & 23 & 15 & 23 & 79 & 45.1 \\
\hline Pearson $\mathrm{r}$ & 13 & 17 & 14 & 11 & 15 & 70 & 40.0 \\
\hline Regresyon & 15 & 10 & 12 & 7 & 11 & 55 & 31.4 \\
\hline Kruskal Wallis & 7 & 9 & 10 & 8 & 8 & 42 & 24.0 \\
\hline Mann Whitney U & 7 & 9 & 8 & 6 & 9 & 39 & 22.3 \\
\hline Kolmogorov Smirnov & 2 & 7 & 3 & 4 & 7 & 23 & 13.1 \\
\hline Path & 1 & 4 & 2 & 1 & 4 & 12 & 6.9 \\
\hline Ki-kare & 1 & 1 & 4 & 2 & 1 & 9 & 5.1 \\
\hline Spearman & 2 & - & 1 & 1 & 3 & 7 & 4.0 \\
\hline Manova & 1 & - & 1 & 1 & - & 3 & 1.7 \\
\hline Ancova & - & - & - & - & 1 & 1 & 0.6 \\
\hline
\end{tabular}

* Bu grupta içerik analizi, yapısal eşitlik modellemesi, moderatör analizi (meta analiz), chaid analizi, panel veri analizi, eta kare ve hiyerarşik lineer modelleme gibi istatistiksel teknikler yer almaktadır.

Tablo 20 'de de görüldüğü üzere Türkiye'de eğitim yönetimi alanında hazırlanan doktora tezlerinde en çok kullanılan istatistiksel tekniğin \%92.0 oran ile betimsel $(\mathrm{n}=161)$ teknik olduğu görülmektedir. Betimsel tekniği sırasıyla, \%65.7 oran ile diğer $(n=115)$ teknikler, $\% 52.0$ oran ile t-testi $(n=91)$ ve $\% 48.0$ oran ile Anova ( $\mathrm{n}=84$ ) takip etmektedir. Türkiye'de eğitim yönetimi alanında hazırlanan doktora tezlerinde en az tercih edilen istatistiksel teknikler ise Ki-kare ( $\% 5.1 ; n=9)$, Spearman $(\% 4.0 ; n=7)$, Manova $(\% 1.7 ; n=3)$ ve Ancova'dir (\%0.6; $\mathrm{n}=1)$.

Tablo 21'de ABD'de eğitim yönetimi alanında hazırlanan doktora tezlerinin kullanılan istatistiksel tekniklere göre dağllıma ilişkin verilere yer verilmiştir.

Tablo 21. ABD'de Eğitim Yönetimi Alannda Hažrlanan Doktora Tęlerinin Kullanulan İstatistiksel Tekniklere Göre Dă̆gllmı

\begin{tabular}{lccccccc}
\hline \multicolumn{1}{c}{ Ístatistiksel Teknik } & 2014 & 2015 & 2016 & 2017 & 2018 & $\boldsymbol{n}$ & \% \\
\hline Diğer* & 41 & 46 & 50 & 45 & 41 & 223 & 65.8 \\
Betimsel & 63 & 36 & 42 & 39 & 42 & 222 & 65.5 \\
t-testi & 16 & 13 & 13 & 13 & 9 & 64 & 18.9 \\
Pearson r & 13 & 7 & 12 & 14 & 8 & 54 & 15.9 \\
Anova & 18 & 8 & 11 & 8 & 5 & 50 & 14.7 \\
Regresyon & 10 & 7 & 7 & 7 & 8 & 39 & 11.5 \\
Ki-kare & 6 & 5 & 3 & 4 & - & 18 & 5.3 \\
Spearman & 2 & 2 & 1 & 3 & 2 & 10 & 3.0 \\
Ancova & 1 & - & 2 & 2 & 2 & 7 & 2.1 \\
Faktör Analizi & 1 & 1 & 2 & 2 & 1 & 7 & 2.1 \\
Mann Whitney U & - & - & - & 1 & 2 & 3 & 0.9 \\
Manova & - & 2 & - & - & 1 & 3 & 0.9 \\
Path & 1 & 1 & - & 1 & - & 3 & 0.9 \\
Kruskal Wallis & - & - & - & - & 1 & 1 & 0.3 \\
\hline
\end{tabular}

* Bu grupta içerik analizi, yapısal eşitlik modellemesi, moderatör analizi (meta analiz), Mancova ve hiyerarşik lineer modelleme gibi istatistiksel teknikler yer almaktadır.

Tablo 21'de de görüldügü üzere ABD'de eğitim yönetimi alanında hazırlanan doktora tezlerinde en çok kullanilan istatistiksel tekniğin \%65.8 oran ile diğer $(\mathrm{n}=223)$ teknikler olduğu görülmektedir. Diğer teknikleri sirasiyla, $\% 65.5$ oran ile betimsel $(\mathrm{n}=222)$ teknik, $\% 18.9$ oran ile t-testi $(\mathrm{n}=64), \% 15.9$ oran ile Pearson $r(n=54), \% 14.7$ oran ile Anova $(n=50)$ ve $\% 11.5$ oran ile regresyon $(n=39)$ takip etmektedir. ABD'de eğitim yönetimi alanında hazırlanan doktora tezlerinde en az tercih edilen istatistiksel teknikler ise Mann Whitney U (\%0.9; $n=3)$, Path ( $\% 0.9 ; n=3)$, Manova (\%0.9; $n=3)$ ve Kruskal Wallis'dir (\%0.3; $n=1)$. 
Tablo 22'de Türkiye'de eğitim yönetimi alanında hazırlanan doktora tezlerinin araştırmacılara yönelik önerilere göre dağılıma ilişkin verilere yer verilmiştir.

Tablo 22. Türkiye'de Eğitim Yönetimi Alannda Hažrlanan Doktora Tez̨lerinin Arașturmacılara Yönelik Önerilere Göre Dă̆gllmı

\begin{tabular}{|c|c|c|c|c|c|c|c|}
\hline Araştırmacılara Yönelik Öneriler & 2014 & 2015 & 2016 & 2017 & 2018 & $n$ & $\%$ \\
\hline İlintili konularla araştırma yapılması & 20 & 27 & 36 & 30 & 29 & 142 & 81.1 \\
\hline Farklı örneklem grupları ile araştırmanın tekrar edilmesi & 19 & 22 & 26 & 28 & 29 & 124 & 70.9 \\
\hline Farklı değişkenler ile araştırmanın tekrar edilmesi & 12 & 15 & 26 & 18 & 22 & 93 & 53.1 \\
\hline Araştırma yönteminin değiştirilmesi (nicel yerine nitel ya da karma) & 14 & 16 & 20 & 17 & 22 & 89 & 50.9 \\
\hline Araştırmanın yurt çapında genişletilmesi & 10 & 7 & 11 & 9 & 17 & 54 & 30.9 \\
\hline Farklı ülkelerle karșılaștırma çalıșmasının yapılması & 3 & 3 & 5 & 4 & 5 & 20 & 11.4 \\
\hline
\end{tabular}

Tablo 22'de de görüldüğü üzere Türkiye'de eğitim yönetimi alanında hazırlanan doktora tezlerinde araştırmacılara yönelik en çok yapılan öneri \%81.1 oran ile "İlintili konularla araştırma yapılması" ( $\mathrm{n}=142)$ önerisidir. Bu öneriyi \%70.9 oran ile "Farklı örneklem gruplanı ile araştırmanın tekrar edilmesi" (n=124) önerisi izlemektedir. Türkiye'de eğitim yönetimi alanında hazırlanan doktora tezlerinde araştırmacılara yönelik en az yapılan öneri ise \%11.4 oran ile "Farklı ülkelerle karşılaşırıma çalışmasının yapılması" ( $\mathrm{n}=20)$ önerisidir.

Tablo 23'te ABD'de eğitim yönetimi alanında hazırlanan doktora tezlerinin araştırmacılara yönelik önerilere dağıllıma ilişkin verilere yer verilmiştir.

Tablo 23. ABD'de Eğitim Yönetimi Alannda Hažrlanan Doktora Tęlerinin Arasstrmaculara Yönelik Önerilere Göre Dă̆gllmı

\begin{tabular}{|c|c|c|c|c|c|c|c|}
\hline Araştırmacılara Yönelik Öneriler & 2014 & 2015 & 2016 & 2017 & 2018 & $n$ & $\%$ \\
\hline İlintili konularla araștırma yapılması & 71 & 68 & 71 & 60 & 48 & 318 & 93.8 \\
\hline Farklı örneklem grupları ile araştırmanın tekrar edilmesi & 61 & 68 & 67 & 64 & 56 & 316 & 93.2 \\
\hline Farklı değişkenler ile araştırmanın tekrar edilmesi & 60 & 65 & 54 & 46 & 45 & 270 & 79.6 \\
\hline Araştırma yönteminin değiştirilmesi (nicel yerine nitel ya da karma) & 34 & 16 & 20 & 18 & 14 & 102 & 30.1 \\
\hline Araştırmanın yurt çapında genişletilmesi & 8 & 6 & 13 & 11 & 10 & 48 & 14.2 \\
\hline Farklı ülkelerle karşılaştırma çalışmasının yapılması & 3 & - & 1 & - & 1 & 5 & 1.5 \\
\hline
\end{tabular}

Tablo 23’te de görüldüğü üzere ABD'de eğitim yönetimi alanında hazırlanan doktora tezlerinde araştırmacılara yönelik en çok yapılan öneri \%93.8 oran ile "İlintili konularla araştırma yapılması" ( $\mathrm{n}=318)$ önerisidir. Bu öneriyi \%93.2 oran ile "Farklı örneklem gruplanı ile araştırmanın tekrar edilmesi" (n=316) önerisi izlemektedir. ABD'de eğitim yönetimi alanında hazırlanan doktora tezlerinde araştırmacılara yönelik en az yapılan önerisi ise \%1.5 oran ile "Farklı ülkelerle karşıllaşırıma çalışmasının yapılması" ( $\mathrm{n}=5)$ önerisidir.

Tablo 24'te Türkiye'de eğitim yönetimi alanında hazırlanan doktora tezlerinin uygulayıcılara yönelik önerilere göre dağılıma ilişkin verilere yer verilmiştir.

Tablo 24. Türkiye'de Ë̆itim Yönetimi Alannda Hažrlanan Doktora Tezlerinin Uygulayıclara Yönelik Önerilere Göre Dă̆gllmı

\begin{tabular}{|c|c|c|c|c|c|c|c|}
\hline Uygulayıcılara Yönelik Öneriler & 2014 & 2015 & 2016 & 2017 & 2018 & $n$ & $\%$ \\
\hline Çalışma koşullarının ve özlük haklarının iyileştirilmesi & 14 & 22 & 32 & 24 & 32 & 124 & 70.9 \\
\hline Hizmet içi eğitim uygulamaları (öğretmen, müdür vb.) & 19 & 24 & 25 & 15 & 25 & 108 & 61.7 \\
\hline Eğitim politikalarının gözden geçirilmesi & 12 & 20 & 27 & 18 & 16 & 93 & 53.1 \\
\hline Eğitim paydaşlarının karara katılımının sağlanması & 15 & 15 & 24 & 22 & 14 & 90 & 51.4 \\
\hline Eğitim yöneticiliğinin yeniden düzenlenmesi & 2 & 12 & 24 & 16 & 15 & 69 & 39.4 \\
\hline Aile eğitimi & 2 & 2 & 4 & 4 & 3 & 15 & 8.6 \\
\hline
\end{tabular}

Tablo 24'te de görüldüğü üzere Türkiye'de eğitim yönetimi alanında hazırlanan doktora tezlerinde uygulayıcılara yönelik en çok yapılan öneri \%70.9 oran ile "Çalışma koşullarının ve özlük haklarının iyileştirilmesi" ( $\mathrm{n}=124)$ önerisidir. Bu öneriyi \%61.7 oran ile "Hizmet içi eğitim uygulamaları (öğretmen, müdür, vb.)” (n=108) önerisi izlemektedir. Türkiye'de eğitim yönetimi alanında hazırlanan doktora tezlerinde uygulayıcılara yönelik en az yapılan öneri ise \%8.6 oran ile "Aile eğitimi" ( $\mathrm{n}=15)$ önerisidir.

Tablo 25’te ABD'de eğitim yönetimi alanında hazırlanan doktora tezlerinin uygulayıcılara yönelik önerilere dağılıma ilişkin verilere yer verilmiştir. 
Tablo 25. ABD'de Ë̆itim Yönetimi Alannda Hažrlanan Doktora Tę̧lerinin Uygulayıclara Yönelik Önerilere Göre Dağıllm

\begin{tabular}{lccccccc}
\hline \multicolumn{1}{c}{ Uygulayıc1lara Yönelik Öneriler } & 2014 & 2015 & 2016 & 2017 & 2018 & $\boldsymbol{n}$ & \% \\
\hline Eğitim politikalarının gözden geçirilmesi & 52 & 44 & 50 & 50 & 46 & 242 & 71.4 \\
Çalışma koşullarının ve özlük haklarının iyileştirilmesi & 50 & 57 & 54 & 44 & 33 & 238 & 70.2 \\
Eğitim yöneticiliğinin yeniden düzenlenmesi & 37 & 47 & 38 & 47 & 40 & 209 & 61.7 \\
Eğitim paydaşlarının karara katıllmının sağlanması & 22 & 53 & 55 & 35 & 36 & 201 & 59.3 \\
Hizmet içi eğitim uygulamaları (öğretmen, müdür vb.) & 24 & 10 & 11 & 19 & 3 & 67 & 19.8 \\
Aile eğitimi & 9 & 3 & 6 & 3 & 4 & 25 & 7.4 \\
\hline
\end{tabular}

Tablo 25'te de görüldüğü üzere ABD'de eğitim yönetimi alanında hazırlanan doktora tezlerinde uygulayıcılara yönelik en çok yapılan öneri \%71.4 oran ile "Eğitim politikalarının gözden geçirilmesi”" ( $n=242)$ önerisidir. Bu öneriyi \%70.2 oran ile "Çalışma koşullarının ve özlük haklarının iyileştirilmesi” $(\mathrm{n}=238)$ önerisi izlemektedir. ABD'de eğitim yönetimi alanında hazırlanan doktora tezlerinde uygulayıcılara yönelik en az yapılan öneri ise \%7.4 oran ile "Aile eğitimi” ( $n=25)$ önerisidir.

\section{Tartışma, Sonuç ve Öneriler}

Araştırma sonuçlarına göre 2014-2018 yılları arasında Türkiye'de toplam 200 doktora tezi hazırlanmıştır. Beş yıllık süreç içerisinde üretilen tez sayısının ortalamasını aldığımızda yıllık 40 doktora tezinin üretildiği görülmektedir. 40 doktora tezinin 21 farklı üniversite bünyesinde hazırlandığını düşünüldügünde ise üniversite başına ortalama 2 tez üretilmektedir. Söz konusu sayının doktora programına sahip bir üniversite için oldukça az olduğu söylenebilir. Üstüner ve Cömert (2008) çalışmalarında 22 yıllık süreçte eğitim yönetimi alanında toplam 204 doktora tezinin hazırlandığını tespit etmiştir. Uysal (2013) da çalışmasında 12 yıllık süreç içerisinde eğitim yönetimi alanında toplam 107 doktora tezinin hazırlandığını tespit etmiştir. Söz konusu sonuçlar araştırmanın sonuçlarıyla benzerlik göstermektedir. 2014-2018 yılları arasında ABD'de ise toplam 1476 doktora tezi hazırlanmıştır. Bu sayının oldukça fazla ve kabul edilebilir düzeyde olduğu söylenebilir. Ancak, üretilen doktora tez sayının fazla olmasında kuşkusuz büyük bir ülke olmasının ve yurt dışından oldukça yoğun bir talep almasının etkilerinden söz edilebilir. Araştırma kapsamında değerlendirmeye alınan doktora tezlerinin yaklaşık yedide biri Eskişehir Osmangazi Üniversitesinde üretilmiştir. Eskişehir Osmangazi Üniversitesini Ankara Üniversitesi ve Hacettepe Üniversitesi takip etmektedir. Ekşi ve Okutan (2007), Altınkurt, Demir, Akbaba Dağ ve Erol (2010), Aydın ve Uysal (2011), Fazlığulları (2012), Uysal (2013) ve Kaya, Yazıcı, Deliveli ve Hoşgörür (2016) de yaptıkları çalışmalarda eğitim yönetimi alanında üretilen lisansüstü tezlerinin büyük çoğunluğunun Ankara Üniversitesi bünyesinde hazırlandığını tespit etmiştir. Söz konusu araştırmaların sonuçlarından da anlaşılacağı üzere elde edilen sonuçlar araştırmanın sonuçlarıyla benzerlik göstermektedir. Türkiye'de hazırlanan erişime açık durumdaki 175 doktora tezinin 166 tanesi eğitim bilimleri enstitüsü bünyesinde hazırlanmıştır. Türkiye'de birçok üniversitede lisansüstü eğitimlerin sosyal, fen ve eğitim bilimleri enstitüleri bünyesinde ayrı ayr1 verildiği bilinmektedir. Bu bağlamda, hazırlanan doktora tezlerinin büyük çoğunluğunun eğitim bilimleri bünyesinde üretilmesi de olası bir durum olarak değerlendirilebilir.

Araştırma sonuçlarına göre hem Türkiye'de hem de ABD'de hazırlanan doktora tezlerinde en çok çalışılan konular örgüt ve örgütsel davranış konuları olmuştur. Aydın, Erdağ ve Sarıer (2010, s.50) çalışmalarında eğitim yönetimi alanında en çok çalışılan konuların örgüt, yönetim ve liderlik olduğunu tespit etmiştir. Aydın ve Uysal (2011, s. 6) da çalışmalarında Türkiye'de hazırlanan doktora tezlerinde en çok örgüt yönetimi ve örgütsel davranış konularına yoğunlaşıldığını tespit etmişlerdir. Ağaoğlu, Ceylan, Kesim, Madden ve Altınkurt (2008, s. 43) da çalışmalarında örgütsel davranış ve liderlik gibi konuların sıklıkla çalışıldığını tespit etmişlerdir. Tatık ve Doğan (2014, s.402) da çalışmalarında üzerinde en çok çalışma yapılan konunun örgüt olduğunu tespit etmiştir. Bahsedilen araştırmaların sonuçlanı elde edilen sonuçlarla benzerlik göstermektedir. Bu durum da alanla ilgili popüler konuların tercih edilmesi gibi bir takım sorunlar yaşandı̆̆ını ortaya koymaktadır (Aydın, Yılmaz ve Altınkurt, 2013, s. 1471). Türkiye'deki temel sorun alanda üretilen bilimsel bilginin, Batılı biliş tarzını esas alarak taklitte boğulması ve her geçen gün özgünlüğünü yitirmesidir (Y1lmaz, 2016, s. 102-104).

Araştırma sonuçlarına göre 2014-2018 yılları arasında Türkiye'de hazırlanan doktora tezlerinde en çok nicel araştırma yöntemi kullanılmıştır. Alanyazın incelendiğinde, söz konusu sonucu destekler nitelikte çok sayıda araştırmaya (Altınkurt vd., 2010; Aydın vd., 2010; Aydın ve Uysal, 2011; Balc1, 1990; Balc1 ve Apaydın, 2009; Ekşi ve Okutan, 2007; Gizir ve Köle, 2009; Yılmaz, 2019) rastlanmaktadır. Bahsi geçen araştırmalarda, yapılan incelemeler sonucunda en çok nicel araştırma yönteminin kullanıldı̆̆ tespit edilmiştir. Bu durum Türkiye'de eğitim yönetimi alanında egemen olan paradigmanın pozitivizm 
olduğunun bir göstergesidir (Yalçın, 2015, s. 189). ABD'de hazırlanan doktora tezlerinde en çok kullanılan yöntem ise nitel araştırma yöntemi olmuştur. Aydın vd. (2010, s. 51) çalışmalarında en çok nitel araştırma yönteminin kullanıldığını tespit etmişlerdir. Aydın ve Uysal (2011, s. 7) da çalışmalarında en çok nitel araştırma yönteminin kullanıldığını tespit etmişlerdir. Söz konusu sonuçlar araştırmanın sonuçlarını destekler niteliktedir.

Araştırma sonuçlanına göre 2014-2018 yılları arasında Türkiye'de hazırlanan doktora tezlerinde en çok kullanılan araştırma modeli tarama modeli olmuştur. Alanyazın incelendiğinde, söz konusu sonucu destekler nitelikte çok sayıda araştırmaya (Ağaoğlu vd., 2008; Balc1, 1988, 1990; Balc1 ve Apaydın, 2009; Tattk ve Doğan, 2014; Turan vd., 2014) rastlamak mümkündür. Söz konusu araştırmalarda, yapılan çalışmalarda en çok tarama modelinin kullanıldığı tespit edilmiştir. Söz konusu sonuçlar araştırmanın sonuçlarıla benzerlik göstermektedir. Hazırlanan doktora tezlerinin büyük çoğunluğunda tarama modelinin tercih edilmesinde pozitif paradigmanın etkisinden söz edilebilir. ABD'de hazırlanan doktora tezlerinde ise Türkiye'dekinin tersi bir durum söz konusudur. ABD'deki tezlerde en çok tercih edilen araştırma modeli durum analizi modelidir. ABD'de hazırlanan doktora tezlerinde en çok kullanılan araştırma yöntemi nitel araştırma yöntemidir. Bu durumun sonucu olarak durum analizinin de hazırlanan doktora tezlerinde çoğunlukla tercih edilmesi olası bir durumdur. Hsu (2005) çalışmasında nitel araştırma yöntemlerinin sıklıkla kullanıldığını tespit etmiş̧ir. Byrd ve Colleen (2009) de çalışmalarında nitel araştırma yöntemlerinin sıklıkla kullanıldığını tespit etmiştir. Söz konusu sonuçlar araştırmanın sonuçlarıyla benzerlik göstermektedir.

Araştırma sonuçlarına göre 2014-2018 yılları arasında Türkiye'de hazırlanan doktora tezlerinde üzerinde en çok araştırma yapılan evren-örneklem grubu öğretmenler olmuştur. Gizir ve Köle (2009), Tattk ve Doğan (2014), Turan vd. (2014) ve Yılmaz (2019) çalışmalarında üzerinde en çok araştırma yapılan evren-örneklem grubunun öğretmenler olduğunu tespit etmiştir. Söz konusu sonuçlar araştırmanın sonuçlarıla benzerlik göstermektedir. Öğretmenlerden sonra üzerinde en çok çalışma yapılan evrenörneklem grubu ise yöneticilerdir. Eğitim yönetimi alanının birincil paydaşları arasında kuşkusuz ögretmenler ve yöneticiler yer almaktadır. Bu nedenle hazırlanan doktora tezlerinde en çok tercih edilen örneklem gruplarının öğretmenler ve yöneticiler olması da olası bir durumdur. Bununla birlikte, örneklem seçiminde kolay ulaşılabilirliğin de etkili olduğu söylenebilir. ABD'de ise üzerinde en çok araştırma yapılan evren-örneklem grubu yöneticilerdir. Yöneticilerden sonra öğretmenler gelmektedir. Günümüzde yaşanan hızlı sosyo-ekonomik, politik ve teknolojik dönüşümler ile birlikte, okul müdürlüğünün geçmişe nazaran daha karmaşık bir duruma geldiği, yeni durumların okul müdürlerinin birden çok alanda liderlik yeterliği kazanmalarını zorunlu hale getirdiği (Gümüşeli, 2001, s. 531) de bilinen bir durumdur. Bu bağlamda, yapilan çalışmalarda öğretmenlerden ziyade okul yöneticileri üzerinde çalışmak normal bir durum olarak değerlendirilebilir.

Araştırma sonuçlarına göre 2014-2018 yılları arasında hem Türkiye'de hem de ABD'de hazırlanan doktora tezlerinde en çok kullanılan örneklem yöntemi amaçlı örnekleme yöntemi olmuştur. Karadağ (2009) ve Uysal (2013) çalışmalarında en çok kullanılan örnekleme yönteminin amaçlı örnekleme yöntemi olduğunu tespit etmiştir. Söz konusu sonuçlar araştırmanın sonuçlarıyla benzerlik göstermektedir. ABD'de hazırlanan doktora tezlerinde en çok kullanılan araştırma yöntemi nitel araştırma yöntemidir. Bu bağlamda, hazırlanan tezlerde örneklem belirlenirken en çok amaçlı örnekleme yönteminin kullanılması da olası bir durumdur. Çünkü diğer bir adı yargısal örnekleme de olan amaçlı örneklemede araştırmacı kimlerin seçileceği konusunda kendi yargısını kullanır ve araştırmanın amacına en uygun olan kişileri örnekleme dâhil eder (Balc1, 2011, s. 102).

Araştırma sonuçlarına göre 2014-2018 yılları arasında Türkiye'de hazırlanan doktora tezlerinde en çok kullanılan veri toplama aracı ölçek olmuştur. Ölçekten sonra en çok kullanılan veri toplama aracı ise görüşme formudur. Karadağ (2009) da çalışmasında en çok kullanılan veri toplama aracının ölçek olduğunu tespit etmiştir. Söz konusu sonuç araştırmanın sonucuyla benzerlik göstermektedir. Türkiye'de hazırlanan tezlerde en çok kullanılan yöntem nicel araştırma yöntemi, en çok kullanılan model ise tarama modeli olmuştur. Bu bağlamda düşünüldüğünde, hazırlanan tezlerde de veri toplama aracı olarak ölçeğin kullanılması olası bir durumdur. ABD'de hazırlanan tezlerde en çok kullanılan veri toplama aracı ise görüşme formudur. ABD'de hazırlanan tezlerde en çok kullanılan yöntem nitel araştırma yöntemi, en çok kullanılan model ise durum analizi modeli olmuştur. Bu nedenle, hazırlanan tezlerde de veri toplama arac1 olarak görüşme formunun kullanılması olası bir durumdur. Blaylock (2004) da çalışmasında hazırlanan tezlerde en çok kullanılan veri toplama aracının araştırmacılar kendileri tarafından geliştirilen tek bir veri 
toplama aracı olduğu tespit etmiştir. Söz konusu da sonuç araştırmanın sonucuyla benzerlik göstermektedir.

Araştırma sonuçlarına göre 2014-2018 yılları arasında Türkiye'de hazırlanan doktora tezlerinin büyük bölümünde geçerlik-güvenirlik bilgilerinin yeterli düzeyde yer aldığı görülmüştür. Altınkurt vd. (2010), Karadağ (2009), Kaya vd. (2016) ve Polat (2010) da çalışmalarında yapılan araştırmalarda geçerlikgüvenirlik bilgilerinin yeterli düzeyde yer aldığını tespit etmişlerdir. Söz konusu sonuçlar araştırmanın sonuçlarıla benzerlik göstermektedir. Türkiye'de hazırlanan tezlerin bazılarında herhangi bir geçerlikgüvenirlik bilgisine rastlanmamıştır. $\mathrm{Bu}$ tezler incelediğinde tezlerin kuram oluşturma ya da doküman analizi gibi çalışmalar olduğu görülmüştür. Bu nedenle herhangi bir geçerlik-güvenirlik bilgisine yer vermedikleri söylenebilir. ABD'de hazırlanan tezlerin çoğunluğunda geçerlik-güvenirlik bilgilerinin kısmen yeterli düzeyde yer aldığı görülmüştür. Ayrıca, hazırlanan tezler incelendiğinde herhangi bir geçerlikgüvenirlik bilgisinin yer almadığı tez sayısı da azımsanmayacak kadar fazladır. Bu oran yaklaşık altı da birdir. Aypay vd. (2010) çalışmalarında inceledikleri araştırmaların büyük bölümünde geçerlik-güvenirlik bilgilerinin belirtilmediğini tespit etmişlerdir. Söz konusu sonuç da araştırmanın sonuçlarıyla benzerlik göstermektedir.

Araştırma sonuçlarına göre 2014-2018 yılları arasında Türkiye'de hazırlanan doktora tezlerinde en çok kullanılan istatistiksel tekniğin betimsel teknik olduğu görülmüştür. Alanyazın incelendiğinde, söz konusu sonucu destekler nitelikte araştırmalara (Aypay vd., 2010; Balc1, 1990; Balc1 ve Apaydın, 2009; Karadağ, 2009; Polat, 2010; Turan vd., 2014) rastlanmaktadır. Söz konusu araştırmalarda, yapılan incelemeler sonucunda en çok kullanılan istatistiksel tekniğin betimsel teknik olduğu tespit edilmiştir. Söz konusu sonuçlar araşırımanın sonuçlarıyla benzerlik göstermektedir. ABD'de hazırlanan doktora tezlerinde en çok kullanılan istatistiksel teknik ise diğer teknikler içerisinde yer alan içerik analizidir. ABD'de hazırlanan tezlerin büyük bölümünde nitel araştırma yöntemi tercih edilmiştir. Bununla birlikte, nitel araştırma yönteminin kullanıldığı çalışmalarda içerik analizi en çok tercih edilen istatistiksel tekniktir. Bu nedenle en çok kullanılan istatistiksel tekniğin içerik analizi olması olası bir durumdur.

Araştırma sonuçlarına göre 2014-2018 yılları arasında hem Türkiye'de hem de ABD'de hazırlanan doktora tezlerinde araştırmacılara yönelik en çok yapılan öneri ilintili konularla araştırma yapılması olmuştur. Bu öneriden sonra en çok yapılan öneriler farklı örneklem grupları ve farklı değişkenler ile araştırmanın tekrar edilmesi olmuştur. Uysal (2013) da çalışmasında araştırmacılara yönelik en çok yapılan önerinin "Benzer ya da alternatif konularda araştırmaların yapılması" önerisi olduğunu tespit etmiştir. Bu öneriden sonra "Farklı örneklem grupları ile araştırmanın tekrar edilmesi" önerisinin sikılıkla tekrar edildiğini ifade etmektedir. Söz konusu araştırmanın sonuçlarından da anlaşılacağı üzere elde edilen sonuçlar araştırmanın sonuçlarılla benzerlik göstermektedir. Elde edilen bu sonuçlar hazırlanan tezlerde benzer önerilerin yapıldığını açıkça göstermektedir. Aslında bir bilimsel çalışmada yer alan öneriler, çalışma sonucunda elde edilen bulguların ve sonuçların pratik ve kuramsal uygulamalara ve sonraki araştırmalara ne gibi katkılar sağlayacağını ifade etmektedir (Karadağ, 2009, s. 212). Bu nedenle, yapılacak olan öneriler bu husus dikkate alınarak yapılmalıdır.

Araştırma sonuçlarına göre 2014-2018 yılları arasında Türkiye'de hazırlanan doktora tezlerinde uygulayıcılara yönelik en çok yapılan öneri çalışma koşullarının ve özlük haklarının iyileştirilmesi olmuştur. $\mathrm{Bu}$ öneriden sonra en çok yapilan öneriler ise hizmet içi eğitim uygulamaları (öğretmen, müdür vb.) ve eğitim politikalarının gözden geçirilmesi olmuştur. Uysal (2013) da çalışmasında uygulayıcılara yönelik en çok yapılan önerinin "Hizmet içi eğitim uygulamaları" önerisi olduğunu tespit etmiştir. Bu sonuç araştırma sonuçlarıla benzerlik göstermektedir. Hazırlanan tezlerin büyük bölümü öğretmenler üzerinde yapıldığ1 için öne çıkan öneriler arasında çalışma koşullarının ve özlük haklarının iyileştirilmesi, hizmet içi eğitim uygulamaları gibi önerilerin yer alması da normal bir durum olarak değerlendirilebilir. ABD'de hazırlanan tezlerde uygulayıcılara yönelik en çok yapılan öneri ise eğitim politikalarının gözden geçirilmesi olmuştur. $\mathrm{Bu}$ öneriden sonra en çok yapılan öneriler çalışma koşullarının ve özlük haklarının iyileştirilmesi ile eğitim yöneticiliğinin yeniden düzenlenmesi olmuştur. ABD'de hazırlanan doktora tezlerinin büyük bölümü yöneticiler üzerinde yapıldığı için eğitim politikaları ve eğitim yöneticiliğinin yeniden düzenlenmesi önerilerinin ortaya çıkması olası bir durum olarak değerlendirilebilir.

Elde edilen bulgular ve yukarıda yapılan tartışmalar doğrultusunda aşağıdaki önerilere yer verilmiştir:

- Ulusal Tez Merkezindeki veriler daha işlevsel hale getirilmelidir. Sisteme yüklenen lisansüstü araştırmalarının hepsi erişime açı hale getirilmelidir. 
- Hazırlanan tezler nicelik açısından değerlendirildiğinde Türkiye'de üretilen tezlerin az sayıda olduğu görülmektedir. Bu bağlamda, genelde lisansüstü eğitime özelde doktora eğitimine gereken önemin verilmesi önerilebilir.

- Hazırlanan tezlerin büyük çoğunluğunda belirli konuların işlendiği görülmektedir. Araştırma konularının seçiminde alanla ilgili ontolojik sorunlar temel alınabilir. Bu bağlamda, fazla çalışma yapılmayan, alana katkı sağlayabilecek ve güncel eğitim sorunlarına çözüm olabilecek konulara da önem verilmesi önerilebilir.

- Hazırlanacak tezlerde araştırmacılar öncelikle kendi yaşadıkları toplumun kültürel ve tarihi gerçeklikleri ile karşı karşıya gelebilirler. Araştırmacılar üretilen bilimsel bilgiyi olduğu gibi alıp kullanmak yerine içinde bulunduklanı toplumsal koşulları dikkate alarak bilgi üretme yoluna yönelebilirler.

- Benzer araştırmalar belirli aralıklarla tekrarlanarak elde edilen sonuçlar önceki araştırma sonuçlarıyla karşılaştırılabilir. Böylelikle eğitim yönetimi alanının genel bir resmini görerek alana katk1 sağlayabiliriz.

- Yapilacak benzer araştırmalar doktora tezlerinin yanı sıra yüksek lisans tezleri ya da eğitim yönetimi alanında yayımlanmış makalelerle de yapılabilir. Böylece eğitim yönetimi alanında üretilen tüm bilgi birikimini görüp alanla ilgili değerlendirme yapma imkânı bulabiliriz.

\section{Etik Beyan}

"Türkiye ve ABD'de Eğitim Yönetimi Alannda Hažrlanan Doktora Tezllerinin Incelenmesi" başlıklı çalışmanın yazım sürecinde bilimsel kurallara, etik ve alıntı kurallarına uyulmuş; toplanan veriler üzerinde herhangi bir tahrifat yapılmamış ve bu çalışma herhangi başka bir akademik yayın ortamına değerlendirme için gönderilmemiştir. $\mathrm{Bu}$ araştırmada doküman incelemesi yapıldığından etik kurul kararı zorunluluğu bulunmamaktadir.

\section{Kaynakça}

Ağaoğlu, E. , Ceylan, M., Kesim, E., Madden, T. ve Altınkurt, Y. (2008). Okul yönetimi ile ilgili lisansüstü tęlerin incelenmesi. Eskişehir: Anadolu Üniversitesi Yayınları.

Altınkurt, Y., Demir, S., Akbaba Dağ, S. ve Erol, E. (2010). Türkiye’de eğitim denetimi alanında yapılan lisansüstü tezlerin değerlendirilmesi. II. Uluslararası Katılıml Eğitim Denetimi Kongresi. Dumlupınar Üniversitesi Eğitim Fakültesi, Kütahya.

Aslan, A. (2018). Sistematik derleme ve meta-analizi. Acta Medica Alanya, 2(2), 62-63.

Aslanargun, E. (2007). Modern eğitim yönetimi anlayışına yönelik eleştiriler ve postmodern eğitim yönetimi. Kuram ve Uygulamada Ë̆itim Yönetimi, 50(50), 195-212.

Aydın, A., Erdağ, C. ve Sarıer Y. (2010). Eğitim yönetimi alanında yayınlanan makalelerinin konu, yöntem ve sonuçlar açısından karş1laştırılması. Eğitim Araştırmalar-Eurasian Journal of Educational Research, 39, 37-58.

Aydın, A. ve Uysal, Ş. (2011). Evaluation of doctoral theses on educational administration in Turkey and abroad, in terms of subjects, methods, and results. Eurasian Journal of Educational Research, 42, 1-14.

Aydın, A., Yılmaz, K. ve Altınkurt, Y. (2013). Eğitim yönetiminde pozitif psikoloji. International Journal of Human Sciences, 10(1), 1470-1490.

Aypay, A., Çoruk, A., Yazgan, D., Kartal, O., Çağatay, M., Tunçer, B. ve Emran, B. (2010). The status of research in educational administration: An analysis of educational administration journals, 1999-2007. Eurasian Journal of Educational Research, 39, 59-77.

Balc1, A. (1988). Eğitim yönetimi araştırmalarının durumu: EAQ’da 1970-1985 arasında yayınlanan araştırmalar. Ankara Üniversitesi Eğitim Bilimleri Fakültesi Dergisi, 21(1), 421-434.

Balc1, A. (1990). Eğitim yönetiminde araştırma. Ankara Üniversitesi Eğitim Bilimleri Fakëltesi Dergisi, 23(1), 81-85.

Balc1, A. (2008). Türkiye'de eğitim yönetiminin bilimleşme düzeyi. Kuram ve Uygulamada Eğitim Yönetimi, 14(2), 181 209.

Balc1, A. (2011). Sosyal bilimlerde araștirma: Yöntem, teknik ve ilkeler. Ankara: Pegem Yayıncilik.

Balcı, A. ve Apaydın, Ç. (2009). Türkiye'de eğitim yönetimi araştırmalarının durumu: Kuram ve uygulamada eğitim yönetimi dergisi örneği. Kuram ve Uygulamada Ë̆itim Yönetimi, 15(59), 325-343.

Beycioğlu, K. ve Dönmez, B. (2006). Eğitim yönetiminde kuramsal bilginin üretimine ve uygulanmasına ilişkin bir değerlendirme. Kuram ve Uygulamada Ë̆itim Yönetimi, 12(3), 317-342.

Blaylock, R. L. (2004). Dissertation integration at Texas A\&M university-commerce educational administration department 19962003: A bistorical research study (Doctoral Thesis). Faculty of the Graduate School, Texas A\&M UniversityCommerce.

Byrd, J. ve Colleen, E. (2009). Statistical applications in two leading educational administration journals. Journal of Educational Administration, 47(4), 508-520. 
Corbin, J. M. ve Strauss, A. (2008). Basics of qualitative research: Techniques and procedures for developing grounded theory (3 $3^{\mathrm{rd}}$ Ed). Thousand Oaks, CA: Sage.

Demirhan, G. (2015). Türkiye'de eğitim yönetimi alanında araştırma geleneği ve paradigmalarn gömülü teori bağlamında değerlendirilmesi (Doktora tezi). Eskişehir Osmangazi Üniversitesi, Eskişehir.

Ekşi, A. ve Okutan, M. (2007). 2000-2003 yılları arasında eğitim yönetimi teftişi planlaması ve ekonomisi alanında yapılmış olan yüksek lisans tez özetleri çalışması. 16. Ulusal Ë̆itim Bilimleri Kongresi. Gaziosmanpaşa Üniversitesi Eğitim Fakültesi, Tokat.

Fazlıŏulları, O. (2012). Türkiye'deki eğitim bilimleri doktora tezlerinin karakteristikleri (Doktora tezi). Ankara Üniversitesi, Ankara.

Gizir, S. ve Köle, F. (2009). Eğitim yönetimi alanında liderlik üzerine yapılan çalışmaların kuram, yöntem ve ele alınan değişken açısından incelenmesi. IV. Ulusal Eğitim Yönetimi Kongresi. Pamukkale Üniversitesi Eğitim Fakültesi, Denizli.

Gümüşeli, A. İ. (2001). Çağdaş okul müdürünün liderlik alanları. Kuram ve Uygulamada Eğitim Yönetimi, 28(28), 531548.

Hsu, T. (2005). Research methods and data analysis proceduresused by educational researchers. Internetional Journal of Research \& Methods in Education, 28(2), 109-133.

Karaçam, Z. (2013). Sistematik derleme metodolojisi: Sistematik derleme hazırlamak için bir rehber. Dokuz Eylül Üniversitesi Hemşirelik. Yükesekokulu Elektronik Dergisi, 6(1), 26-33.

Karadağ, E. (2009). Türkiye'de eğitim bilimleri alanında yapılmıs doktora tęlerinin tematike ve metodolojik açıdan incelemesi: Bir durum çalıs̆ması (Doktora tezi). Marmara Üniversitesi, İstanbul.

Karakütük, K. (1989). Türkiye lisansüstü öğretim, sorunları ve çözüm önerileri. Ankara Üniversitesi Eğitim Bilimleri Fakültesi Dergisi, 22(1), 505-528.

Karaman, S. ve Bakırcı, F. (2010). Türkiye'de lisansüstü eğitim: Sorunlar ve çözüm önerileri. Sosyal Bilimler Arastırmalar Dergisi, 5(2), 94-114.

Kaya, C.., Yazıcı, A. Ş., Deliveli, K. ve Hoşgörür, V. (2016). Türkiye'de eğitim denetimi alanında yapılan lisansüstü çalışmaların değerlendirilmesi. Adnan Menderes Üniversitesi Ë̆itim Fakültesi Eğitim Bilimleri Dergisi, 7(1), 38-51.

Konan, N. ve Kış, A. (2013). ABD'de eğitim yönetimi alanında yapılan doktora tezlerinin çözümlenmesi. Euluslararası Ë̆itim Arastırmaları Dergisi, 4(1), 100-123.

Littell, J. H. (2006). Systematic reviews in the social sciences: A review. Evidence \&o Policy, 2(4), 535-537.

Oplatka, I. (2016). Eğitim yönetiminin mirası (S. Turan, F. Bektaş ve M. Yalçın, Çev.). Ankara: Pegem Yayıncılık.

Petticrew, M. ve Roberts, H. (2006). Systematic reviews in the social sciences a practical guide. Oxford: Blackwell Publishing Ltd.

Polat, G. (2010). Eğitim yönetimi ve denetimi anabilim dalında yapılmıs lisansüstü tę çalısmalarnnn incelenmesi (Doktora tezi). Maltepe Üniversitesi, İstanbul.

Şentuna-Akay, E. (2019). İçerik analizine giriş. İçinde A. Arı (Çev. Edt.). Sosyal Bilimlerde Nitel Araştırma Yöntemleri (s. 343-380). Konya: Eğitim Yayınevi.

Tatık, R. Ş. ve Doğan, S. (2014). Marmara üniversitesi eğitim yönetimi ve denetimi alanındaki yüksek lisans tezlerinin incelenmesi. The Journal of Academic Social Science Studies, 25-I, 399-410.

Tavşançıl, E. ve Aslan, A. E. (2001). Söz̧el, yaz̨ll ve diğer materyaller için içerik analiz̨i ve uygulama örnekleri. İstanbul: Epsilon Yayınevi.

Turan, S., Karadağ, E., Bektaş, F. ve Yalçın, M. (2014). Türkiye'de eğitim yönetiminde bilgi üretimi: Kuram ve uygulamada eğitim yönetimi dergisi 2003-2013 yayınlarının incelenmesi. Kuram ve Uygulamada Egütim Yönetimi, 20(1), 93-119.

Turan, S. ve Şişman, M. (2013). Eğitim yönetimi alanında üretilen bilimsel bilgi ve batılı biliş tarzının eleştirisine giriş. Kuram ve Uygulamada Eğitim Yönetimi, 19(4), 505-514.

Uysal, Ş. (2013). Türkiye'de eğitim yönetimi teftişi planlamasi ve ekonomisi alanndaki doktora tez̨lerinin incelenmesi (Doktora tezi). Eskişehir Osmangazi Üniversitesi, Eskişehir.

Üstüner M. ve Cömert M. (2008). Eğitim yönetimi, teftişi, planlaması ve ekonomisi anabilim dalı lisansüstü dersleri ve tezlerine ilişkin bir inceleme. Kuram ve Uygulamada Ĕ̈itim Yönetimi, 14(3), 497-515.

Varış, F. (1972). Türkiye'de lisansüstü eğitim. Ankara Üniversitesi Eğitim Bilimleri Fakültesi Dergisi, 5(1), 51-74.

Yalçı, M. (2015). Batı kaynakh bilginin Türk akademisindeki rolü: Eğitim yönetimi alanımn değerlendirilmesi (Doktora tezi). Eskişehir Osmangazi Üniversitesi, Eskişehir.

Yıldırım, A. ve Şimşek, H. (2008). Sosyal bilimlerde nitel araştırma yöntemleri. Ankara: Seçkin Yayınları.

Yılmaz, K. (2015). Eğitimin temel kavramları. İçinde H. B. Memduhoğlu ve K. Yılmaz (Edt.). Eğitim bilimine giriş (s. 120). Ankara: Pegem Akademi Yayıncılık.

Yılmaz, K. (2016). Türkiye'de eğitim yönetimi alanındaki batı etkisi üzerine bir değerlendirme. İçinde K. Yılmaz (Edt.). Elestirel eğitim yönetimi yąılar (s. 65-114). Ankara: Pegem Akademi Yayıncılık.

Yılmaz, K. (2018). Türkiye'deki eğitim yönetimi alanı ile ilgili çalışmalara eleştirel bir bakış. Journal of Human Sciences, 15(1), 123-154.

Yılmaz, K. (2019). Türkiye'de eğitim yönetimi alanında yapılan örgütsel davranıs makalelerindeki yönelimler. Türkiye Eğitim Dergisi 4(2), 81-103.

Yılmaz, K. (2021). Sosyal bilimlerde ve eğitim bilimlerinde sistematik derleme, meta değerlendirme ve bibliyometrik analizler. Manas Sosyal Arastermalar Dergisi, 10(2), 1457-1490. 


\section{EXTENDED ABSTRACT}

Education is a process that affects all aspects of a person's life from birth to death. Because people are involved in a social learning activity from birth to death. In this context, education has an important place in determining the future of societies (Yllmaz, 2015, p. 1). Postgraduate education is a planned and programmed education process that aims to produce science and technology by research, after the completion of undergraduate education, and has undertaken the mission of raising scientists who will play an important role in the development and development of the country (Varsş, 1972, p. 52). The graduate education brings some problems along with the realization of the determined goals. One of these problems is the qualification problems in the prepared graduate thesis. In this context, it is necessary to examine the postgraduate thesis prepared in a specific field and to present a general picture of the field.

Educational administration is a field that entered the process of creating its own identity in the second half of the 20th century and started to be considered as a separate field of study. The field of educational administration was inevitably affected by the theoretical developments observed in various fields during this period and the reflections of these theories on the field of administration (Beycioğlu \& Dönmez, 2006, p. 323-324). However, Turkey ranks first among the countries where scientific knowledge produced in the field of educational administration is transferred intensively. In order to see this situation, it will be sufficient to take a look at the terminology in the relevant literature (Turan \& Şişman, 2013, p.506).

As a result of the review of the relevant literature, a small number of comparative studies (Aydin \& Uysal, 2011; Konan \& Kiş, 2013) conducted on the examination of PhD thesis in the field of educational administration were found. From this point of view, this comparison study will be made is considered important in terms of filling the gap in the relevant literature and revealing the general view of the relevant field. The main purpose of this research is to evaluate the $\mathrm{PhD}$ thesis prepared in the field of educational administration in Turkey and USA between the years of 2014-2018 in terms of demographic characteristics, subjects, methods and suggestions. In line with this main purpose, answers to the following questions were sought:

1. What are the demographic characteristics (year, university, and institute) of $\mathrm{PhD}$ thesis prepared in the field of educational administration in Turkey and America between 2014-2018 years?

2. How is the distribution of $\mathrm{PhD}$ thesis prepared in the field of educational administration in Turkey and USA between 2014-2018 years in terms of subject?

3. How is the distribution of $\mathrm{PhD}$ thesis prepared in the field of educational administration in Turkey and USA between 2014-2018 years in terms of the methods (quantitative, qualitative, and mixed) used?

a. How is the distribution of $\mathrm{PhD}$ thesis prepared in the field of educational administration in Turkey and USA between 2014-2018 years in terms of research model (scanning, causal, relational, etc.)?

b. How is the distribution of $\mathrm{PhD}$ thesis prepared in the field of educational administration in Turkey and USA between 2014-2018 years in terms of population and sample groups?

c. How is the distribution of $\mathrm{PhD}$ thesis prepared in the field of educational administration in Turkey and USA between 2014-2018 years in terms of sampling methods?

d. How is the distribution of $\mathrm{PhD}$ thesis prepared in the field of educational administration in Turkey and USA between 2014-2018 years in terms of data collection tools?

e. How is the distribution of $\mathrm{PhD}$ thesis prepared in the field of educational administration in Turkey and USA between 2014-2018 years in terms of validity-reliability studies?

f. How is the distribution of $\mathrm{PhD}$ thesis prepared in the field of educational administration in Turkey and USA between 2014-2018 years in terms of statistical techniques used in data analysis?

4. Under which headings are the suggestions that are thought to contribute to the field in the $\mathrm{PhD}$ thesis prepared in the field of educational administration in Turkey and USA between 2014-2018 years?

The research was designed as a systematic review study. The universe of the study consists of $\mathrm{PhD}$ thesis that prepared in the field of educational administration in Turkey and in USA between 2014-2018 years. For the $\mathrm{PhD}$ thesis in Turkey, there was not made sample selection but was tried to reach the entire universe. $175 \mathrm{PhD}$ thesis prepared in the field of educational administration in Turkey are included into 
the study. The stratified sampling and the simple random sampling methods were used to determine the $\mathrm{PhD}$ thesis in USA. It was determined that $1476 \mathrm{PhD}$ thesis prepared in the field of educational administration in USA. The sample was determined as 306 for $95 \%$ confidence level. However, in order to increase the validity and reliability of the study, $339 \mathrm{PhD}$ thesis were included into the sample.

According to the findings most of the $\mathrm{PhD}$ thesis in the field of educational administration in Turkey was prepared in 2017, while in USA was prepared in 2014. The issues most studied in the $\mathrm{PhD}$ thesis prepared in Turkey and in USA are the organization and organizational behavior and administration. In the $\mathrm{PhD}$ thesis, quantitative research method and teachers as sample group was most preferred in Turkey, while qualitative research method and administrators as sample group was most preferred in USA. In thesis, while certain issues are frequently studied in both countries, it was given little attention to some issues. It can be seen the effect of positivist paradigm in the thesis prepared in Turkey. Similar suggestions have been made for the researchers in the PhD thesis in both countries. 